\title{
Evaluating the Budget and Efficiency of the Security, Justice and Governance Cluster in Uganda: \\ An Empirical Analysis
}

BYAMUGISHA, Albert | BASHEKA, Benon C.

\section{Abstract}

Derformance measurement has
increasingly become central to the efficiency and effectiveness of any government - developed or developing. The introduction of public sector reforms, which transferred most service delivery obligations to the private sector under the New Public Management (NPM) doctrines, demanded a strong performance measurement framework. Sequel to continual government's role in public service delivery in the last decade coming under attack, a revival interest in the exact role of government in public services delivery has thus become imperative. Evaluating performance of different sectors of government is paramount and provides useful information for effective decision-making. This article presents empirical findings of the Government Half Annual Performance Report for the security, justice and governance cluster. The objective is to highlight areas where progress has been made against the set targets and actions and where delays have been occasioned within the context of Uganda. These findings however are useful in guiding different actors including Cabinet and line Ministries, Departments, Agencies and Local governments in ensuring that agreed targets are met at the end of the Financial Year.

Keywords: Government efficiency, Evaluation, Performance measurement, Selfassessment, Uganda. 
Evaluating the Budget \& Efficiency of the Security, Justice \& Governance Cluster in Uganda 27

\section{Introduction}

Any serious public reform initiative intended to measure results and the degree of effectiveness need to establish institutional mechanisms in which results information can be collected and used in planning and budgeting and this has an effect on resource allocation and decision-making in that country as Porter, (2013:3) suggests. Mofolo, Mkuyana and Skande (2014:5) support this and demonstrate to their audiences how monitoring and evaluation are critical tools for government institutions to be effective in their aspirations to create an impact in the lives of citizens. It is no longer a matter of intense debate how public expectations worldwide regarding the role of the state in providing public goods and services remains on the increase and will possibly remain so in the years to come especially more so when the trust governments had bestowed on private sector as a key driver of public services delivery has come under heavy attack from citizens. M\&E is fundamental in the transformation of the public sector if it is to be efficient, effective and responsive to citizens but this requires increased capacity by governments to demand results-orientated monitoring (tracking what they have planned to do), and also asking deeper questions of why and how, through evaluations of policies and programmes (Porter, 2013:2).

Government, world over, are now challenged to find new and more efficient ways to deliver public goods and services to the citizens. Indeed, Government's role in public service delivery in the last decade has led to a revival of scholarly and practitioner interest in public services in developing countries (Batley, McCourt and Mcloughlin, 2011:3). On its part, evaluation has increasingly captured the interest of evaluation theorists, researchers, and practitioners (Lennie, Tacchi, \& Wilmore, 2010:2; Cousins, Goh, Elliott \& Bourgeois, 2014:5). Evaluation is increasingly seen as an ongoing learning process and an important means of strengthening capacity and improving organisational performance (Horton et al., 2003: 7). The need for evaluation has received immense attention in almost all types of organizations and the public sector has become a major consumer of numerous evaluations; albeit the utilization of evaluation findings remaining in a deficit. The things to be evaluated (evaluands) now range from laws, products, services, organisations, people, processes, and the social state of affairs of any kind (Stockman \& Meyer, 2013:67).

In line with the Constitutional provision of the Government of Uganda, Article 108A, entrusts the Prime Minister of the country to effectively coordinate Government 
policies across Ministries, Departments and Agencies and reports to Cabinet every six months on their performance. The Office of the Prime Minister (OPM) produces two reports covering every Financial Year (FY) - i.e. The Government Half-Annual Performance Report (GHAPR) and the Government Annual Performance Report (GAPR). While the former focuses on the government performance in first half of the $F Y$, the latter encompasses performance for the entire FY. This article is derived from the halfyear performance assessments but with a significant pointer on likely performance of the sectors under review by end of the financial year.

The current GHAPR is the eleventh ever since the inception of the reforms in Government performance assessment that started with the pilot for quarter 3 of $\mathrm{FY}$ 2008/09. The analysis in the article highlights which outputs (products and services) and actions are likely to be achieved by year-end given the rate of implementation at the half-year stage, which may be achieved if the rate of implementation is accelerated and which are unlikely to be achieved at the current rate, and therefore need attention. The scope of the assessment is the period July to December 2014 across the all sectors that constitute the annual planning and budgeting framework respective MDAs. The outputs, their indicators and associated targets, and actions outlined in FY2014/15 Ministerial Policy Statements are used as the framework for the analysis Outcomes are only measured during the annual assessment, and are therefore excluded from this half-year assessment. The performance information in the GHAPR for the FY2014/15 is generated from the analysis of the data from MDA sector submissions through the Output Budgeting Tool (OBT).

The debates on quality of service delivery in Uganda provide a reason for undertaking empirical evaluations. The government performance assessment provides a good case for investigating issues of service delivery for other reasons as well. First, current policy debates casts doubt on whether supply side factors such policies, funds are the most important factors for improved service delivery given the fact that increased key sector budgetary resources that have coincided with reduced performance. Consequently, this article provides empirical evidence on how successful MDAs can improve on their performance. Second the choice of security cluster for the study will provide an insight in the implementation of policy recommendations on quality of livelihood of the citizens. Finally, although the focus of this article is on the security 
Evaluating the Budget \& Efficiency of the Security, Justice \& Governance Cluster in Uganda 29

cluster, the implications of the findings can be extended to other clusters receiving government resources.

\section{Objectives of the Study}

The objective of the study was to provide timely and focused information to Cabinet and other decision- makers on Government's progress towards its targets at the halfway stage of the financial year. The purpose was to enable Cabinet and Ministries identify areas where emphasis needs to be put to achieve the set targets by the end of the financial year. The analysis was done sector by sector, and then grouped into the economic functions of Government, and focused on four aspects of public sector performance:

(i) Progress made against planned outputs and use of resources

(ii) Progress made in terms of outputs against funds released

(iii) Assessment of financial releases and expenditures

(iv) Explanations for the performance levels achieved

\section{Literature Review}

The importance of evaluation in influencing positive decision making cannot be over emphasized. Porter (2013:3) is of the strong view that evaluation helps to establish what difference has been made, why the level of performance could have been achieved, what lessons are being learned from activities, and whether and how to governments can use the lessons to strengthen implementation of their programmes or policies This view is supportive of Kitamur (2009:2) who reported how evaluation of past policies constituted what he regarded an indispensable part of public policy formulation. Citizens urgently need better services from their governments but are not getting so due to serious impairments in the public service delivery systems. Thinking about public services has reflected the way the public policy pendulum has swung in both developing and industrialized countries: a movement towards the market and a smaller state, and then a reassertion of government's role (Batley, McCourt and Mcloughlin, 2011:2).

Porter (2013:2) is also of the opinion that when decision-makers, whether political or bureaucratic, want to use evidence from $M \& E$ systems to assist them in making decisions, the demand for M\&E needs to be emphasized. Governments must assess how the public service systems are working or not. In his public service revival call, Coats 
(2006: i) demonstrates how contrary to the experience of the last thirty years, there remains a need for a deep-rooted political consensus about how public services should be managed. Establishing a well-founded agreement, which recognizes the importance of the public realm, and accepts the need for flexibility and diversity in provision of services as well as placing democracy at the centre of a new model of public management is regarded a critical challenge for adoption. The focus of this article on the security, Justice and Governance cluster is therefore not out of context.

African Governments; Uganda inclusive, increasingly operate in an environment of unprecedented changes driven by technological transformations; as facilitated by internet. Within this environment, Governments have found themselves challenged on what should be their appropriate size and role in service delivery. The role of the private sector and other non-state actors has complicated the debate on what exactly should be the role of government. There is an emerging consensus among scholars and practitioners pointing to a positive correlation between the mode of regulation/regulatory practices in public administration systems and 'good governance' (Bana, 2014:81). Baldwin, et al (1998:14) as well as Jordana and Levi-Faur (2004:4) broadly conceptualize regulation by including all the mechanisms which are not the products of state activity, nor part of any institutional arrangement, such as the development of social norms, and the effects of markets in modifying behaviour.

Within the public sector the budget fulfils the same task as an economic market because it establishes what public services are to be supplied to the public, what individuals or groups will receive the public services, how these public services will be delivered and how, as well as with what costs of the services are to be financed (Gildenhuys, 1997: 391). Hague (2003:1) makes us believe that evaluation Capacity Development (ECD) helps countries build sound governance hence improving transparency and building a performance culture within governments to support better management and policymaking, including the budget process-through support for the creation or strengthening of national/sectoral monitoring and evaluation systems.

Learning from evaluation studies requires a multidisciplinarity given the complex nature of government operations. While authors like Rabie and Cloete (2009:77) state that public policy analysis and general social science are the two main disciplines that influence evaluation research, the influences can actually come from other fields depending on what is being evaluated. For instance, evaluation of the security sector 
Evaluating the Budget \& Efficiency of the Security, Justice \& Governance Cluster in Uganda 31

performance owes its legitimacy from the methods used and these can be obtained from disciplines beyond social research. Nonetheless as Rabie and Cloete, (2009:77) contend, evaluation must be undertaken in order to compare alternatives before choices amongst them. To be most effective, organisations however need to invest in evaluations capacity building activities at the management level as opposed to only the staff level (Atkinson et al. 2005: 63). For them to be effective and successful, organisations need to design appropriate strategies (Horton et al. 2003:555). In addition as Porter (2013:3) asserts, the institutional design of government M\&E systems is important, including the systems for capturing, processing, storing and communicating M\&E information. Monitoring helps managers and policymakers to understand what the money invested is producing and whether plans are being followed.

\section{Methodology \\ Data Collection}

The Office of the Prime Minister (OPM) draws data from the Output Budgeting Tool (OBT) for analysis, including checking for completeness, and where possible, accuracy, through triangulation against previous year's performance, and other sources of information. The assessment report relies primarily on secondary data, provided by the Ministries Departments and Agencies/Sectors from OBT. The OBT was designed by Ministry of Finance Planning and Economic Development (MoFPED) to incorporate Sector performance indicators for key inputs, outputs and outcomes.

Financial information is drawn from the Government Integrated Financial Management System (IFMS) and related systems, such as Legacy. The financial information in this report excludes taxes and arrears. Additional data provided by the sectors and by the Uganda Bureau of Statistics (UBOS) pertains to key outcome indicators that are not currently captured in the BFPs, and explanatory information that details the reasons for good and poor performance. Where constraints continue to exist in the OBT regarding the provision of detailed explanatory information, the Ministries Departments and Agencies (MDAs) provide supplements to the OBT detailing the reasons for good and, especially, under-performance. Subsequently, the data is analysed, tabulated, and written-up sector by sector. The sector reports are then compiled into an overall national report (GHAPR) for the Rt. Hon. Prime Minister to present to Cabinet. 


\section{Data Analysis}

The report provides two levels of analyses. The first level takes a comprehensive assessment of all performance indicators outlined in Sector Budget Framework Papers and associated Ministerial Policy Statements while the second level of analysis focuses on the key performance areas and issues in each sector. A scorecard is used which measures the progress made at half financial year against specific targets set in the relevant Ministerial Policy Statements. The targets are set at three levels but two are considered during the half annual assessment. The first is the outputs, which are the specific deliverables that are financed by the budget, and identified by each M DA in their Budget Framework Papers. As the budget is appropriated annually, the targets are also annual. By half year it is also possible to assess how many of the outputs are on truck and how many are lagging behind. The second analysis is the budget. The last two rows of the table provide the financial information from the Budget. This shows how much money has been budgeted for the financial year and how much has been released at half year by the Treasury to the Sector, and then how much of that money has been absorbed or spent. These are key indicators of whether or not the Sector and its Ministries, Departments and Agencies have had the means to implement their programmes and achieve the targets or not.

A rating system is applied to all outputs to assess progress. Figure 1.1 illustrates the rating system for outputs based on progress at the half-year stage. The system is applied to each individual MDA output and the scores are aggregated by MDA and sector using "traffic light" system as shown in Figure 1.1.

Figure 1.1: Physical Performance Rating System

$\begin{aligned} & \text { Likely to be } \\ & \text { Achieved }\end{aligned}$
$\begin{aligned} & \text { Where the level of progress against the target at the half-year stage is } \\ & \text { likely to be achieved at the current rate of implementation by the end of } \\ & \text { the Financial Year, calculated on the basis of 50\% or greater than the } \\ & \text { annual target reached at the half-year stage. i.e. pro-rate progress }\end{aligned}$
$\begin{aligned} & \text { Where the level of progress against the target at the half-year } \\ & \text { stage is borderline, meaning that the target or action may be } \\ & \text { achieved if additional effort is made, calculated on the basis of a } \\ & \text { performance level between } 30 \% \text { and } 49 \% \text { of the annual target at the } \\ & \text { half-year stage. }\end{aligned}$


Evaluating the Budget \& Efficiency of the Security, Justice \& Governance Cluster in Uganda 33

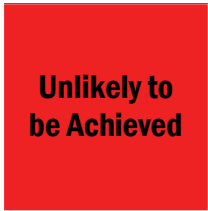

No
Where the level of progress against the target or action at the halfyear stage is considerably below what was planned, and the target is unlikely to be achieved at the current rate of implementation by the end of the Financial Year. This reflects where the percentage of the annual target reached at the half-year stage is less than $30 \%$.

Where insufficient or no data or information has been provided, an assessments not possible.

Figure 1.2 outlines efficiency assessment that links the progress made against an output with the amount of funds released by the MFPED to that output. Where the progress made is equivalent to, or greater than the resources availed, the judgment is that delivery is in line with the release. Where the progress being made is less than the amount of funds released, the judgment is that delivery is not in line with the release. While it is recognized that implementation progress is in part a factor of the timing and size of the release, this measure of performance is aimed at assisting Cabinet, Ministers and Permanent Secretaries in providing an illustration of implementation progress against resources availed at this mid-year point.

\section{Figure 1.2: Efficiency Assessment Rating System}

Delivery in line with release

\section{Delivery not in line with release}

Where the level of progress towards each output at the half-year stage is commensurate to, or greater than, the amount of funds* released

Where the level of progress towards each output at the half-year stage is less than the amount of funds* released.

*Government of Uganda component only (excluding donor funds which are not reported on at output level). 


\section{Findings and Discussions}

The Security, Justice and Governance cluster includes the sectors of Accountability, Justice, Law and Order, Legislature, Public Administration, Public Sector Management and Security. Below we present the evaluation findings on each of these sectors based on the physical and efficiency rating system described in the methodology. The centrality of each of these sectors in running an effective government is undisputed. We begin with the accountability sector whose objectives include effective budget preparation and monitoring, increasing citizens' demand for accountability; establishing value for money in service delivery; compliance to procedures and efficient tax collection. Accountability is one of the cornerstones of good governance; however, it can be difficult for scholars and practitioners alike to navigate the myriad of different types of accountability. Recently, there has been a growing discussion within both the academic and development communities about the different accountability typologies.

\section{The Accountability Sector}

The Sector is led by the Office of the Accountant General and comprises of the Office of the Auditor General (OAG), Directorate of Ethics and Integrity (DEI), the Ministry of Finance, Planning and Economic Development (MoFPED), Inspectorate of Government (IG), Uganda Bureau of Statistics (UBOS), Public Procurement and Disposal of Assets Authority (PPDA), Uganda Revenue Authority (URA). In the evaluation the efficiency of each of the sub-sector was assessed and results are presented. This is preceded however by the overall performance of the whole sector.

The Accountability Sector received UGX 425.33bn, which translates into 59\% of the annual approved budget for the FY 2014/15 of UGX 717.84bn (GoU and External financing). Overall, the Sector absorbed $93 \%$ of the budget released by half-year. The overall sector performance indicates that $50 \%$ of the output indicator targets are likely to be achieved at current rate of implementation, 21\% may be achieved while $29 \%$ of the output indicator targets is unlikely to be achieved by the end of the financial year. The efficiency assessment of the sector performance indicates that, the delivery on $55 \%$ of the output indicators was in line with the release of funds by half year while delivery on $45 \%$ of the output indicators was not in line budget release. 
Evaluating the Budget \& Efficiency of the Security, Justice \& Governance Cluster in Uganda 35

Table 1.1: Half-Year Performance Scorecard for Accountability Sector

OUTPUT PERFORMANCE

\begin{tabular}{|l|c|c|c|c|c|}
\hline & $\begin{array}{c}\text { Likely to be } \\
\text { Achieved }\end{array}$ & $\begin{array}{c}\text { May be } \\
\text { Achieved }\end{array}$ & $\begin{array}{c}\text { Unlikely to be } \\
\text { Achieved }\end{array}$ & No Assessment & Denominator \\
\hline Sector & $50 \%$ & $\mathbf{2 1} \%$ & $29 \%$ & $\mathbf{0} \%$ & $\mathbf{7 5}$ \\
\hline MoFPED & $52 \%$ & $24 \%$ & $24 \%$ & $0 \%$ & 29 \\
\hline PPDA & $67 \%$ & $0 \%$ & $33 \%$ & $0 \%$ & 3 \\
\hline URA & $75 \%$ & $25 \%$ & $0 \%$ & $0 \%$ & 4 \\
\hline OAG & $43 \%$ & $29 \%$ & $28 \%$ & $0 \%$ & 7 \\
\hline UBOS & $42 \%$ & $33 \%$ & $25 \%$ & $0 \%$ & 12 \\
\hline IG & $47 \%$ & $12 \%$ & $41 \%$ & $0 \%$ & 17 \\
\hline DEI & $33 \%$ & $0 \%$ & $67 \%$ & $0 \%$ & 3 \\
\hline
\end{tabular}

BUDGET PERFORMANCE

\begin{tabular}{|l|r|r|r|r|r|c|}
\hline Budget & \multicolumn{1}{|c|}{$\begin{array}{c}\text { Approved } \\
\text { (UGX Bn) }\end{array}$} & $\begin{array}{r}\text { Released } \\
\text { (UGX Bn) }\end{array}$ & $\begin{array}{c}\text { Spent } \\
\text { (UGX } \\
\text { Bn) }\end{array}$ & $\begin{array}{c}\text { \% of } \\
\text { budget } \\
\text { release }\end{array}$ & $\begin{array}{c}\text { \% of } \\
\text { release } \\
\text { spent }\end{array}$ & $\begin{array}{c}\text { \% of } \\
\text { budget } \\
\text { spent }\end{array}$ \\
\hline Sector Total & $\mathbf{7 1 7 . 8 4}$ & $\mathbf{4 2 5 . 3 3}$ & $\mathbf{3 9 7 . 6 7}$ & $\mathbf{5 3 . 3 \%}$ & $\mathbf{9 3 . 5 \%}$ & $\mathbf{5 5 . 4 \%}$ \\
\hline MoFPED & 265.28 & 138.15 & 125.58 & $52.1 \%$ & $90.9 \%$ & $47.3 \%$ \\
\hline PPDA & 10.76 & 4.39 & 3.36 & $40.8 \%$ & $76.4 \%$ & $31.2 \%$ \\
\hline URA & 235.32 & 117.11 & 117.11 & $49.8 \%$ & $100.0 \%$ & $49.8 \%$ \\
\hline OAG & 51.37 & 40.96 & 31.96 & $79.7 \%$ & $78.0 \%$ & $62.2 \%$ \\
\hline UBS & 111.56 & 99.38 & 99.32 & $89.1 \%$ & $99.9 \%$ & $89.0 \%$ \\
\hline IG & 38.12 & 22.62 & 18.21 & $59.3 \%$ & $80.5 \%$ & $47.8 \%$ \\
\hline DEI & 5.42 & 2.70 & 2.13 & $49.9 \%$ & $78.7 \%$ & $39.3 \%$ \\
\hline
\end{tabular}


EFFICIENCY ASSESSMENT

\begin{tabular}{|l|c|c|c|c|}
\hline & $\begin{array}{c}\% \text { where output } \\
\text { performance is in line } \\
\text { with budget released }\end{array}$ & $\begin{array}{c}\text { \% where output } \\
\text { performance is not in } \\
\text { line with budget } \\
\text { released }\end{array}$ & $\begin{array}{c}\text { No } \\
\text { Assessment }\end{array}$ & Denominator \\
\hline Sector Total & $55 \%$ & $45 \%$ & $0 \%$ & 75 \\
\hline MoFPED & $38 \%$ & $62 \%$ & $0 \%$ & 29 \\
\hline PPDA & $100 \%$ & $0 \%$ & $0 \%$ & 3 \\
\hline URA & $75 \%$ & $25 \%$ & $0 \%$ & 4 \\
\hline OAG & $43 \%$ & $57 \%$ & $0 \%$ & 7 \\
\hline UBOS & $62 \%$ & $38 \%$ & $0 \%$ & 12 \\
\hline IG & $76 \%$ & $24 \%$ & $0 \%$ & 17 \\
\hline DEI & $33 \%$ & $67 \%$ & $0 \%$ & 3 \\
\hline
\end{tabular}

Source: Sectors OBT, FY 2014/15

The performance of individual sub-sectors is presented below according to the evaluation findings of this study.

\section{Ministry of Finance, Planning and Economic Development}

The Ministry of Finance, Planning and Economic Development (MoFPED) received 49\% of its approved annual budget of UGX 235.32bn (GoU and External financing) and spent all the funds released by half-year. The mid-year performance assessment indicates that $52 \%$ of the output indicator targets are likely to be achieved at the current rate of implementation, $24 \%$ may be achieved and $24 \%$ of the output indicator targets are unlikely to be achieved. In relation to the release, $38 \%$ of the output indicators were delivered in line with spending. The delivery of $62 \%$ of the output indicators was not in line with level of spending.

\section{1) Macroeconomic Management}

The Ministry performed well in monitoring and analysis of macroeconomic policy, and providing tax appeal tribunal services. As a measure to improve tax administration, URA efficiency and tax policy measures were monitored and their impact on revenue performance evaluated. By half-year, 4 tax amendment Bills were produced as planned and $50 \%$ of progress reports on macroeconomic model was produced. The Tax Appeals Tribunal resolved disputes worth UGX $1750 \mathrm{bn}$ at half-year against annual target of UGX 205bn translating into 854\%. 
Evaluating the Budget \& Efficiency of the Security, Justice \& Governance Cluster in Uganda 37

Taxpayers were sensitized on tax litigation and arbitration procedures to create awareness in 2 of 4 planned sensitization workshops. There was slow progress in Domestic Revenue and Foreign Aid Policy, Monitoring and Analysis with external resource mobilization equivalent to $6 \%$ of the national budget. The Ministry monitored 50 MDAs as planned and produced 6 (43\%) of the planned revenue performance reports.

\section{- Budget Preparation and Execution}

There was good progress in coordinating and monitoring both national and Local Government (LG) budget cycles. The arrears as percentage of total expenditures for FY 2011/12 were 1.4\% against annual target of 3\%. There was good absorption at half-year with utilization of $88 \%$ of the funds released against annual target of $98 \%$. The Ministry analyzed and consolidated Sector Budget Framework Papers for FY 2015/16 into the National Budget Framework Paper and conducted the National Budget Consultative workshop for FY 2015/16.

\section{- Public Finance Management}

There was slow progress in public finance management. Despite good performance in payroll audit and upgrading Navision Financial Management System in Uganda's Foreign Missions, there was slow progress in auditing foreign missions and IT activities due to inadequate resources. Only of the 3 public universities was piloted on the computerized education management and accounting system. The slow progress was due to failure to produce Treasury Memoranda. The Ministry was still waiting responses from the affected persons in the 4 draft treasury memoranda prepared in first quarter. On development and management of internal audits and controls, the Ministry had not inspected any of the 40 PDEs planned since the inspection tool was being reviewed.

\section{- Economic Development and Policy Research}

The Ministry performed well in monitoring, analysing and providing advisory services, and population development services to inform Government decision on economic policy and national development. By half-year, the Ministry analyzed 6 sectors as planned and produced 2 key economic publications against annual target of 4 publications. $73 \%$ of work on Fiscal reconciliation of 
final accounts for the FY 2013/14 was completed, $85 \%$ of the work on the Annual Economic Performance Report for FY 2013/14, 80\% of work on the Public expenditure analysis report (PEAR) for FY 2013/14 completed and the Policy Implementation Issues Paper for FY 2013/14 finalized. The Ministry provided Technical Support Supervision and guidance on how to use the National Population Policy Action Plan to $37 \%$ of 60 district planning units.

\section{- Investment and Private Sector Promotion}

In promoting investment and creating conducive investment environment, the Ministry performed well in developing entrepreneur skills and enterprise Uganda services, with $71 \%$ of 4000 of rural and urban participants mobilized and trained to start businesses. The good performance level was attributed to high demand for entrepreneurship and business skills short-term trainings. There was slow progress in monitoring investment and private sector policy framework. None of the 5 planned Investor Protection Agreements (IPAs) was concluded and business-licensing reforms were not implemented by half-year. The slow progress in this result area was attributed to inadequate funding to conduct the second investor survey and short term consultancy services for review of IPAs, investment policy development and development of private sector development strategy.

\section{- Microfinance}

The Ministry of Finance, Planning and Economic Development ensure sustainable delivery of affordable financial services countrywide. During the period under review, the Ministry performed quite well in establishing microfinance framework. The Ministry strengthened 160 SACCOs through capacity building against annual target of 300 SACCOs and 340 were provided specialized training. The Microfinance Support Centre Ltd, Disbursed 60 loans i.e. $99 \%$ of the planned 100 loans. The Credit department focused on loan disbursement, delinquency management and Constant loan follow up to enforce recoveries. However, there was slow progress in establishing SACCOs in subcounties with 15\% SACCOs registered against annual target of 2200. Uganda Microfinance Regulatory Authority (MRA) was not established since the Tier IV 
Microfinance Bill that gives legal existence to UMRA to regulate the institutions is not yet passed into Law by Parliament.

\section{Public Procurement and Disposal of Public Assets Authority}

The Public Procurement and Disposal of Public Assets Authority (PPDA) received $40 \%$ of its approved annual budget of UGX 10.76bn (GoU and External financing) and spent all the funds released by half-year. In terms of performance, PPDA is likely to achieve on $67 \%$ of its output indicator targets by the end of the financial year. It is unlikely that the authority will achieve its target on inspection of MDAs at current rate of implementation. Considering the release, all the output indicators were delivered in line with spending indicating that the Authority was very efficient in delivering its outputs during the period under review. PPDA performed well in procurement audits and investigations. The authority completed $55 \%$ of the planned 80 procurement audits, and made followed up of audit and investigations recommendations. There was slow progress in monitoring compliance with PPDA law, with $31 \%$ of 150 planned MDAs inspected by mid-year. The Procurement Performance Management System (PPMS) verification can be carried out the third and fourth quarter after the entities have input considerable amount of data in the PPMS.

\section{Uganda Revenue Authority}

The Uganda Revenue Authority (URA) received $49 \%$ of its approved annual budget of UGX 235.32bn (GoU and External financing) and spent all the funds released by halfyear. In terms of performance, $75 \%$ of the output indicators of the URA are likely to be achieved at current rate of implementation and the Authority may achieve its annual target on growth in tax register with additional efforts. The delivery of $75 \%$ of the output indicators was in line with release. Delivery on growth in tax register was not in line with release. The authority performed well in customs and domestic tax collection, achieving the quarterly targets in tax collection at mid-year.

Custom revenue collection for the half-year period was UGX 2,087.75bn against a target of UGX 2,087.61bn, a performance of $100 \%$ as planned. The performance of Custom taxes during the half year is attributed to growth in the major rateable imports by $19 \%$ (UGX 723.96bn) due to efficient automated customs valuation and Single Customs Territory (SCT) which simplified the customs clearance processes and improved 
the customs valuation and the turnaround time. The arrears of Customs reduced by $61 \%$ from UGX 51.981bn as at 30 th June 2014 to UGX 20.2151bn as at 30 ${ }^{\text {th }}$ December 2014. The Domestic tax collection for the half-year was UGX 2,578.1bn against a target of UGX $2,565.85 \mathrm{bn}$, a performance of $100 \%$ as planned. The level of Domestic tax performance is attributed to improved profitability in the banking sector, which led to increased remittances by UGX $20.7 \mathrm{bn}$ and efficient revenue collection by UMEME through installation of YAKA ${ }^{4}$.

The average filing ratio for both tax heads (VAT and LED) was 76\% against annual target of $88 \%$, representing $87 \%$ performance level. Out of the total collectible arrears of UGX 261.55bn in half-year, UGX $149.75 \mathrm{bn}$ was collected, a performance of $57.2 \%$. A total of UGX $149.75 \mathrm{bn}$ debt was collected from a debt stock of UGX 400.33bn, representing debt reduction by $37.4 \%$. There was slow progress in tax register, with $11 \%$ growth in tax register realised against annual target of 30\% representing 37\% level of performance. The annual target may though be achieved with additional effort.

\section{Office of the Auditor-General}

The Office of the Auditor General (OAG) received 79\% of its approved annual budget of UGX $51.36 \mathrm{bn}$ and $78 \%$ of the funds released was absorbed by half-year. In terms of performance, $43 \%$ of the output indicators of the OAG is likely to be achieved at current rate of implementation, $29 \%$ may be achieved with additional efforts while $28 \%$ is unlikely to be achieved at current rate of implementation. Considering budget performance, $43 \%$ of the output indicators were delivered in line with release. The delivery of $57 \%$ of the output indicators was not in line with level of release.

The performance in financial audits was quite well, with $78 \%$ of 46 planned forensic investigations and special audits conducted. A total of 73 special audits were in progress. It is worth-noting that special audits are carried out on request hence the actual may either be lower or higher than the planned. The target for auditing Higher Local Governments (LGs) including Town councils and sub-counties ${ }^{5}$ was achieved by half-year.

\footnotetext{
${ }^{4}$ A prepaid electricity system.

${ }^{5}$ The 1,108 audits include 1058 Sub-Counties and 50 schools. The 1,058 Sub-Counties include a backlog of 571 Sub-Counties that were work in progress by end of March 2014. However, a total of 470 audits (111 districts, 22 Municipal Councils, 150 schools, 174 Town councils and 13 RRHs) were at the audit report processing stage.
} 
Evaluating the Budget \& Efficiency of the Security, Justice \& Governance Cluster in Uganda 41

There was slow progress in auditing Ministries, Departments and Agencies (MDAs), projects and statutory bodies. Only 3\% of 109 MDAs audited, 41\% of 134 projects audited and $34 \%$ of 91 planned statutory bodies were audited by half-year. The management letters to audit the remaining institutions (MDAs and statutory bodies) and projects were being prepared. There was underperformance in value for money (VFM) audit. None of the 16 value for money audits planned for FY 2013/14 was completed by mid-year. A total of 13 VFM audits were in progress and the final reports are expected to be produced by end of March 2015. The 2 PPP audits were postponed to FY 2015/16 awaiting approval of the audit guidelines.

\section{Uganda Bureau of Statistics}

Uganda Bureau of Statistics (UBOS) received $89 \%$ of its approved annual budget of UGX $111.562 \mathrm{bn}$, and utilized $99 \%$ of the funds released to deliver on outputs. The performance of the bureau in half-year was below average with $42 \%$ of its output indicators is likely to be achieved by the end of the financial year. $33 \%$ of the output indicators may be achieved with more efforts, while $17 \%$ output indicators is unlikely to be achieved. In relation to budget performance, $62 \%$ of the output indicators were delivered in line with release indicating that the Bureau was very efficient in delivering its outputs during the period under review. The delivery of $38 \%$ of the output indicators was not in line with level of release.

Uganda Bureau of Statistics performed quite well in providing statistics on the economic, social and population indicators, maintaining statistical system database, and industrial and agriculture indicators. The GDP figures, inflation rates, international trade and ggovernment finance statistics on a monthly quarterly and basis. On industrial and agriculture indicators, the bureau compiled industrial/producer price indices and construction and energy sector statistics monthly. The UBOS website and the national statistical database were updated and operational at half-year.

There was slow progress in building capacity and district statistics. Only 14\% of 139 Higher Local Government was able to compile District Annual Statistical Abstracts and only $36 \%$ of 112 districts were implementing community information system (CIS) by half-year. The Higher Local Government profiles reports was not produced and disseminated by half-year. Underperformance in this area was attributed to the engagements in National Housing and Population Census (NPHC). 


\section{Inspectorate of Government}

The Inspectorate of Government (IG) received $59 \%$ of its approved annual budget of UGX 38.12bn (GoU and External financing), and $80 \%$ of the money received was utilized to deliver on outputs. The performance was however below with $47 \%$ of output indicators likely to be achieved by the end of the financial year and $12 \%$ output indicators maybe achieved with additional effort. The remaining output indicators are unlikely to be achieved at current rate of implementation. Taking into account budget performance, $76 \%$ of the output indicators were delivered in line with release indicating that the Inspectorate was very efficient in delivering its outputs. The delivery of $24 \%$ of the output indicators was not in line with level of release. The inspectorate performed well on prosecutions and civil litigations, and education and public awareness. On prosecution and civil litigations, $92 \%$ of 12 judicial review cases concluded and $56 \%$ of 50 corruption cases prosecuted and completed. On education and public awareness, the inspectorate supported $60 \%$ of 20 partnerships and institutions and half of the IEC materials developed and disseminated.

There was slow progress in investigations and verification of leader's declaration and ombudsman complaints, policy and system study. On investigations, 30\% of corruption complaints were investigated and completed against annual target of $85 \%$ equivalent to $35 \%$ level of progress. By half-year, no backlogged case was completed because investigations take long time and the risks associated. The increasing complexity and changing faces of corruption affected the output performance. On verification of leaders' declaration, the leaders have failed to comply with the leadership code. By half-year, the leaders required to file declaration forms did not do so and they were expected to file declaration forms in March 2015. The Inspectorate investigated 30\% of 20 leaders for breach of leadership code. The delayed amendment of the leadership code act, lack of proper record keeping, lack of proper urban planning and difficulty in accessing various registries has affected the result area. On ombudsman complaints, policy and system study, the inspectorate conducted only $25 \%$ of 8 systemic investigations. The performance level is attributed to reluctance of some government institutions to provide information for system studies on time and lack of record keeping in government institutions which makes it difficult to obtain vital information. 
Evaluating the Budget \& Efficiency of the Security, Justice \& Governance Cluster in Uganda 43

\section{Directorate of Ethics and Integrity}

The Directorate of Ethics and Integrity (DEI) received $49 \%$ of its approved annual budget of UGX 5.42bn (GoU and External financing), and $78 \%$ of the funds received was utilized to deliver on outputs. The performance was however below with only $33 \%$ of output indicators likely to be achieved by the end of the financial year and the remaining output indicators are unlikely to be achieved at current rate of implementation. With respect to budget performance, $33 \%$ of the output indicators were delivered in line with release while $67 \%$ of the output indicators were not in line with level of release. The Directorate performed well in formulation and monitoring of policies and laws, with 2 IAF working groups (PEC Technical working Group, ACPPP Task Force) were functional against annual target of 4 IAF working groups. There was underperformance in public education and awareness, and coordination of national anti-corruption strategy. The capacity of only $13 \%$ of 8 District Integrity Promotion Forum (DIPFs) was developed by half-year under public education and awareness. On coordination of anti-corruption strategy, National Anti-Corruption Strategy (NACS) was disseminated to only $25 \%$ of 40 planned districts.

\section{JUSTICE LAW AND ORDER SECTOR}

The key Sector objectives are to strengthen legal and policy frameworks for JLOS operations and national development; enhanced access to JLOS services particularly for the vulnerable persons and; promotion of observance of human rights and accountability. The Ministry of Justice and Constitutional Affairs (MoJCA) leads the Justice, Law and Order Sector (JLOS). Other sector members include: the Judiciary, Ministry of Local Government (Local Council Courts), Ministry of Gender Labour and Social Development (Juvenile Justice Department), Uganda Law Reform Commission, the Directorate of Public Prosecutions (DPP), Judicial Service Commission, Uganda Law Society, Uganda Prisons, Uganda Police Force, Uganda Human Rights Commission (UHRC), Law Development Centre (LDC), Ministry of Internal Affairs, National Citizenship and Immigration Control, Uganda Registration Services Bureau, Centre for Alternative Dispute Resolution (CADER) and the Tax Appeals Tribunal (TAT).

The approved budget for the JLOS Sector for FY2014/15 was UGX807.92bn donor component inclusive and UGX $807.34 \mathrm{bn} \mathrm{GoU}$, and the release by half year was UGX437.75bn (54\%), of which $83 \%$ was spent. Progressive performance assessment of 
the sector output indicators shows that $63 \%$ of the indicators are likely to be achieved, $10 \%$ may be achieved with additional effort and $24 \%$ is unlikely to be achieved by end of the financial year at the current rate of implementation. $3 \%$ of the output indicators were not assessed due to insufficient data especially under Ministry of Justice and Constitutional Affairs. On average, $64 \%$ of the sector output indicators were delivered in line with released funds. The institutions that performed above the average (50\%) of likelihood to achieve their annual targets by FY2014/15 include: Ministry of Justice and Constitutional Affairs, The Judicial Service Commission, Ministry of Internal Affairs, the Directorate of Public Prosecutions, Uganda Human Rights Commission, Uganda Prisons Services, Uganda Police Force, Law Development Centre and Directorate of Citizenship and Immigration Control. The institutions that performed below average are The Judiciary (0\%), Law Reform Commission (33\%) and Uganda Registration Services Bureau (40\%) and hence the need for additional efforts by the institutions in the remaining half of the year.

\section{Ministry of Justice and Constitutional Affairs}

The Ministry was allocated UGX39.98bn of which UGX29.39bn (74\%) was released in the first half of the FY 2014/15, and UGX 20.98bn (71\%) spent. Performance assessment shows that $60 \%$ of the output indicators targets are likely to be achieved, $20 \%$ is unlikely to be achieved at the current rate of implementation, while $7 \%$ may be achieved if additional effort is made and $13 \%$ of the output indicators was not assessed due to insufficient data especially on inspection and supervision of law firms and legal aid service providers. Efficiency assessment shows that $67 \%$ of the output indicators were delivered in line with the release of funds, $20 \%$ was not delivered in line with the release while $13 \%$ could not be assessed due insufficient data.

The Ministry is progressing well on a few output indicators which include drafting and publication of bill ( $67 \%$ of 15 bills drafted), opening new files for estates clients and inspection of estates at $69 \%$ and $100 \%$ against the annual targets of 4000 files and 100 estates respectively; arbitrating and mediating families already achieving the annual target at 116 against the target of 1000), disposal of disciplinary cases (65\% against target of 200 cases)- attributed to additional funding provided to Law Council Department by JLOS project support to weed out backlogged, and functionality of basic JLOS frontline services in districts at $7.2 \%$ against target of $12 \%$. An area where the 
Evaluating the Budget \& Efficiency of the Security, Justice \& Governance Cluster in Uganda 45

Ministry may achieve annual target if additional effort is made is payment of Courts awards arrears $(0.32 \%$ against target of $1 \%)$. However, the Ministry is unlikely to achieve the following: reduction of ex parte judgements against Attorney General (10\% of $100 \%$ ), winding up of estates (4\% of 80 ), payment of current Court awards and arrears $(0.21 \%$ of $2 \%)$ - attributed to due to inadequate provision in the Medium Term Expenditure Framework ceiling.

Table 1.2: Half-Year Performance Scorecard for Justice, Law and Order Sector

OUTPUT PERFORMANCE

\begin{tabular}{|l|c|c|c|c|c|}
\hline & $\begin{array}{c}\text { Likely to be } \\
\text { Achieved }\end{array}$ & $\begin{array}{c}\text { May be } \\
\text { Achieved }\end{array}$ & $\begin{array}{c}\text { Unlikely to } \\
\text { be } \\
\text { Achieved }\end{array}$ & $\begin{array}{c}\text { No } \\
\text { Assessment }\end{array}$ & Denominator \\
\hline Sector & $\mathbf{6 3 \%}$ & $\mathbf{1 0 \%}$ & $\mathbf{2 4 \%}$ & $\mathbf{3 \%}$ & $\mathbf{1 2 0}$ \\
\hline MoJCA & $60 \%$ & $7 \%$ & $20 \%$ & $13 \%$ & 15 \\
\hline Judiciary & $0 \%$ & $38 \%$ & $62 \%$ & $0 \%$ & 8 \\
\hline JSC & $67 \%$ & $0 \%$ & $33 \%$ & $0 \%$ & 6 \\
\hline Internal Affairs & $68 \%$ & $4 \%$ & $24 \%$ & $4 \%$ & 25 \\
\hline DPP & $89 \%$ & $0 \%$ & $11 \%$ & $0 \%$ & 9 \\
\hline UHRC & $67 \%$ & $0 \%$ & $33 \%$ & $0 \%$ & 3 \\
\hline UPS & $70 \%$ & $10 \%$ & $20 \%$ & $0 \%$ & 10 \\
\hline UPF & $82 \%$ & $18 \%$ & $0 \%$ & $0 \%$ & 17 \\
\hline LRC & $33 \%$ & $0 \%$ & $67 \%$ & $0 \%$ & 6 \\
\hline LDC & $50 \%$ & $25 \%$ & $25 \%$ & $0 \%$ & 8 \\
\hline Immigration & $88 \%$ & $0 \%$ & $12 \%$ & $0 \%$ & 8 \\
\hline URSB & $40 \%$ & $20 \%$ & $40 \%$ & $0 \%$ & 5 \\
\hline
\end{tabular}

BUDGET PERFORMANCE

\begin{tabular}{|l|c|c|c|c|c|c|}
\hline \multicolumn{1}{|c|}{ Budget } & $\begin{array}{c}\text { Approved } \\
\text { (UGX Bn) }\end{array}$ & $\begin{array}{c}\text { Released } \\
\text { (UGX Bn) }\end{array}$ & $\begin{array}{c}\text { Spent } \\
\text { (UGX Bn) }\end{array}$ & $\begin{array}{c}\% \text { of } \\
\text { budget } \\
\text { release }\end{array}$ & $\begin{array}{c}\% \text { of } \\
\text { release } \\
\text { spent }\end{array}$ & $\begin{array}{c}\% \text { of } \\
\text { budget } \\
\text { spent }\end{array}$ \\
\hline $\begin{array}{l}\text { Sector Total } \\
\text { (GoU+Donor) }\end{array}$ & 807.92 & 437.75 & 364.93 & $54 \%$ & $83 \%$ & $45 \%$ \\
\hline Sector Total (GoU) & 807.34 & 437.75 & 364.93 & $54 \%$ & $83 \%$ & $45 \%$ \\
\hline MoJCA (GoU+Donor) & 39.98 & 29.39 & 20.98 & $74 \%$ & $71 \%$ & $52 \%$ \\
\hline MoJCA (GoU) & 39.98 & 29.39 & 20.98 & $74 \%$ & $71 \%$ & $52 \%$ \\
\hline Judiciary (GoU+Donor) & 84.04 & 42.35 & 40.37 & $50 \%$ & $95 \%$ & $48 \%$ \\
\hline Judiciary (GoU) & 83.46 & 42.35 & 40.37 & $51 \%$ & $95 \%$ & $48 \%$ \\
\hline JSC (GoU+Donor) & 3.18 & 1.66 & 1.43 & $52 \%$ & $86 \%$ & $45 \%$ \\
\hline
\end{tabular}


46 Africa's Public Service Delivery \& Performance Review

\begin{tabular}{|l|c|c|c|c|c|c|}
\hline \multicolumn{1}{|c|}{ Budget } & $\begin{array}{c}\text { Approved } \\
\text { (UGX Bn) }\end{array}$ & $\begin{array}{c}\text { Released } \\
\text { (UGX Bn) }\end{array}$ & $\begin{array}{c}\text { Spent } \\
\text { (UGX Bn) }\end{array}$ & $\begin{array}{c}\% \text { of } \\
\text { budget } \\
\text { release }\end{array}$ & $\begin{array}{c}\% \text { of } \\
\text { release } \\
\text { spent }\end{array}$ & $\begin{array}{c}\% \text { of } \\
\text { budget } \\
\text { spent }\end{array}$ \\
\hline JSC (GoU) & 3.18 & 1.66 & 1.43 & $52 \%$ & $86 \%$ & $45 \%$ \\
\hline $\begin{array}{l}\text { Internal Affairs } \\
\text { (GoU+Donor) }\end{array}$ & 10.90 & 5.90 & 5.47 & $54 \%$ & $93 \%$ & $50 \%$ \\
\hline Internal Affairs (GoU) & 10.90 & 5.90 & 5.47 & $54 \%$ & $93 \%$ & $50 \%$ \\
\hline DPP (GoU+Donor) & 21.98 & 12.44 & 7.18 & $57 \%$ & $58 \%$ & $33 \%$ \\
\hline DPP (GoU) & 21.98 & 12.44 & 7.18 & $57 \%$ & $58 \%$ & $33 \%$ \\
\hline UHRC (GoU+Donor) & 9.7 & 5.27 & 4.37 & $54 \%$ & $83 \%$ & $45 \%$ \\
\hline UHRC (GoU) & 9.7 & 5.27 & 4.37 & $54 \%$ & $83 \%$ & $45 \%$ \\
\hline UPS (GoU+Donor) & 94.33 & 46.95 & 41.95 & $50 \%$ & $89 \%$ & $44 \%$ \\
\hline UPS (GoU) & 94.33 & 46.95 & 41.95 & $50 \%$ & $89 \%$ & $44 \%$ \\
\hline UPF (GoU+Donor) & 403.06 & 202.74 & 165.79 & $50 \%$ & $82 \%$ & $41 \%$ \\
\hline UPF (GoU) & 403.06 & 202.74 & 165.79 & $50 \%$ & $82 \%$ & $41 \%$ \\
\hline LRC (GoU+Donor) & 7.39 & 3.99 & 3.49 & $54 \%$ & $88 \%$ & $47 \%$ \\
\hline LRC (GoU) & 7.39 & 3.99 & 3.49 & $54 \%$ & $88 \%$ & $47 \%$ \\
\hline LDC (GoU+Donor) & 5.40 & 4.05 & 4.05 & $75 \%$ & $100 \%$ & $75 \%$ \\
\hline LDC (GoU) & 5.40 & 4.05 & 4.05 & $75 \%$ & $100 \%$ & $75 \%$ \\
\hline $\begin{array}{l}\text { Immigration } \\
\text { (GoU+Donor) }\end{array}$ & 119.25 & 78.67 & 66.55 & $66 \%$ & $85 \%$ & $56 \%$ \\
\hline Immigration (GoU) & 119.25 & 78.67 & 66.55 & $66 \%$ & $85 \%$ & $56 \%$ \\
\hline URSB (GoU+Donor) & 8.72 & 4.35 & 3.3 & $50 \%$ & $76 \%$ & $38 \%$ \\
\hline URSB (GoU) & 8.72 & 4.35 & 3.3 & $50 \%$ & $76 \%$ & $38 \%$ \\
\hline
\end{tabular}

\section{EFFICIENCY ASSESSMENT}

\begin{tabular}{|l|c|c|c|c|}
\hline & $\begin{array}{c}\text { \% where output } \\
\text { performance is in line } \\
\text { with budget released }\end{array}$ & $\begin{array}{c}\text { \% where output } \\
\text { performance is not in } \\
\text { line with budget } \\
\text { released }\end{array}$ & $\begin{array}{c}\text { No } \\
\text { Assessment }\end{array}$ & Denominator \\
\hline Sector Total & $\mathbf{6 4 \%}$ & $\mathbf{3 2 \%}$ & $\mathbf{4 \%}$ & $\mathbf{1 2 0}$ \\
\hline MoJCA & $67 \%$ & $20 \%$ & $13 \%$ & 15 \\
\hline Judiciary & $0 \%$ & $100 \%$ & $0 \%$ & 8 \\
\hline JSC & $67 \%$ & $33 \%$ & $0 \%$ & 6 \\
\hline Internal Affairs & $79 \%$ & $21 \%$ & $0 \%$ & 25 \\
\hline DPP & $89 \%$ & $11 \%$ & $0 \%$ & 9 \\
\hline UHRC & $33 \%$ & $67 \%$ & $0 \%$ & 3 \\
\hline UPS & $80 \%$ & $20 \%$ & $0 \%$ & 10 \\
\hline UPF & $82 \%$ & $18 \%$ & $0 \%$ & 17 \\
\hline LRC & $17 \%$ & $83 \%$ & $0 \%$ & 6 \\
\hline
\end{tabular}


Evaluating the Budget \& Efficiency of the Security, Justice \& Governance Cluster in Uganda 47

\begin{tabular}{|l|c|c|c|c|}
\hline & $\begin{array}{c}\text { \% where output } \\
\text { performance is in line } \\
\text { with budget released }\end{array}$ & $\begin{array}{c}\text { \% where output } \\
\text { performance is not in } \\
\text { line with budget } \\
\text { released }\end{array}$ & $\begin{array}{c}\text { No } \\
\text { Assessment }\end{array}$ & Denominator \\
\hline LDC & $50 \%$ & $50 \%$ & $0 \%$ & 8 \\
\hline DCIC & $88 \%$ & $12 \%$ & $0 \%$ & 8 \\
\hline URSB & $40 \%$ & $60 \%$ & $0 \%$ & 5 \\
\hline
\end{tabular}

\section{The Judiciary}

The Institution received UGX42.35bn (50\%) against the approved annual budget of UGX84.04bn donor inclusive and spent UGX40.37bn (95\% by half-year). Despite this expenditure, the half annual performance assessment of the Judiciary indicates that none of the annual output targets are likely to be achieved at the current rate of implementation; only $38 \%$ may be achieved with additional efforts and $62 \%$ is unlikely to be achieved at the current rate of implementation. Analysis of the output performance vis-à-vis the budget released shows that appalling level of efficiency with $0 \%$ of output indicators delivered in line with the release of funds while. The Judiciary should critically address the performance bottlenecks for her to deliver on the targeted outputs.

Assessment shows that the Judiciary may achieve the following areas if additional effort made; timely disposal of civil appeals in the Supreme Court (46\% out of 35 cases), timely disposal of civil appeals in the Court of Appeal (49\% out of 200 cases) and disposal of suits (Family, Criminal, Civil, Land and Anti-Corruption) in the Magistrates Courts (36\% out of 123,919). As reported by Judiciary, the slow disposal of Suits and Appeals in the Magistrate Courts is attributed to lack of registrars which has resulted into Chief Magistrates to act as registrars hence increasing workload. Similarly, the Magistrates Grade one Courts lack adequate facilitation in terms of computerisation and transport required to visit mandatory locus in quo for land matters.

The Judiciary is unlikely to achieve the set targets on disposal of criminal appeals in the Supreme Court both at $11 \%$ (5 out of 45 criminal cases), disposal of Criminal appeals in the Court of Appeal at 23\% (92 against 400 cases) and disposal of criminal and civil suits and appeals in the High Court (family, land, civil and commercial) at $29 \%$ and $8 \%$ of the targeted 12500 criminal and 2500 civil cases 
respectively. The slow performance progress is attributed to lack of substantive leaders in the Supreme Court and Court of Appeal, and limited number of sessions due to few judges in the High Court.

\section{Judicial Service Commission}

The Judicial Service Commission received UGX1.66bn by half year against an approved annual budget of UGX3.18bbn, and spent UGX1.43bn (86\%) of the release. Outputs performance assessment indicates that $67 \%$ of the indicators are likely to be achieved and $33 \%$ unlikely to be achieved current rate of implementation by the end of the FY 2014/15. Analysis of efficiency in delivery of outputs against the release of funds shows that $67 \%$ output targets were delivered in line with the release of funds.

The Commission registered good performance progress in disposal rate ${ }^{6}$ of investigated cases already achieving the annual target of $75 \%$ as well as investigation ${ }^{7}$ of registered complaints at $50 \%$, the average time taken to recruit judicial officers up to Chief Magistrate (at 3 months against target of 4 months)- where 27 Judicial Officers were recruited and submitted to the Judiciary for deployment to the different Courts of Judicature, average taken to make recommendations for appointment of judges to the President (at 3 months). By half year, submissions for the appointment of Chief Justice, Deputy Chief Justice, Chairperson of the Tax Appeals Tribunal, Chairperson of Electricity Disputes Tribunal, Vice-Chairperson of Electricity Disputes Tribunal and Registrar of the Electricity Disputes Tribunal had been made to the H.E the President. The analysis shows that the Commission is unlikely to achieve the annual targets in public awareness and participation in justice administration where only 8 against targeted 36 radio talk shows were held in Soroti, Lira, Mbale and Jinja.

\section{Ministry of Internal Affairs}

By the half year, the Ministry had received UGX5.47bn (54\%) of the approved budget UGX10.9bn and spent $93 \%$ of the release. The assessment of output indicators shows

\footnotetext{
${ }^{6} 10$ Disciplinary Committee meetings were held and 2 Investigations trips carried out in the Magisterial areas of: Gulu, Kiryandongo, Nakasongola, Luwero, Mengo, Nakawa, Mbarara, Bushenyi, Rukungiri, Ibanda, Mukono, Entebbe, Kajjansi,Wakiso, Mwanga II, Makindye, Kiira and Buganda Road Court.

72 Workshops for complainants' sensitisation held in Lukaya Town Council and Bukulula; 1 Investigative trip carried out at Mwanga II Road Magistrates' Court.
} 
Evaluating the Budget \& Efficiency of the Security, Justice \& Governance Cluster in Uganda 49

the Ministry is likely achieve $68 \%$ and unlikely to achieve $24 \%$ of the annual targets at the current rate of implementation while $4 \%$ may be achieved if additional effort is made and $4 \%$ not assessed due to insufficient data. The efficiency assessment indicates that $79 \%$ of the output indicators were delivered in line with the released funds. The annual targets that the Ministry had made good progress by half year are on establishment of peace committees (3 out of 5) and training of peace committees members in conflict prevention and management resolutions (50\% of 100) in the districts; identification of security regions with obsolete and surplus arms, unexploded ordnances and explosive remnants of wars for disposal (4 out of 5); provision of psychosocio and reinsertion support to reporters at $89 \%$ of 100 and $93 \%$ of 130 respectively; issuance and supervision of community service orders (66\% of 8800 ), identification of eligible offenders and reintegration of offenders already at $194 \%$ and $187 \%$ of 4000 and 1600 respectively-attributed to increased number of volunteers at Courts and increased networking with Uganda Prisons Service.

Other areas of good progress include facilitation of District Community Service Committees (82\% of 17); maintenance of average time taken to register an NGO at 60 days in which 427 NGOs were registered and monitoring of NGOs (77 out of 100). The Ministry also improved the average time taken (days) to resolve an NGO dispute from 60 to 30 days due to identification of technical staff to handle the complaints, and hence the process is now faster since they are always available. The Ministry may achieve the following annual targets with additional effort; demobilisation of reporters $34 \%$ of targeted 200). However, annual targets on identification of unexploded ordnances and explosives for destruction, sensitization of district task force under small arms and light weapons and studies on prevalence of antibiotics in milk, meat and products are unlikely to be achieved at the current of implementation.

\section{Directorate of Public Prosecutions}

The approved annual budget for Directorate of Public Prosecution (DPP) was UGX21.98bn out of which, UGX12.44bn (57\%) was released and UGX7.18bn (83\%) of the release spent by half-year. The assessment of output performance indicates that $89 \%$ of the output indicators are likely to be achieved and $11 \%$ unlikely to be achieved at the current rate of implementation. The assessment of the level of efficiency at half year 
also shows that $89 \%$ for output indicators delivered in line with the release of funds which is good progress performance.

Examples of key performance indicators that showed good progress include: average time spent concluding prosecution-led investigations where32 investigations were concluded in average of 120 days (this is however higher compared to the 100 days recorded in first half of the previous year); average time taken to peruse a case file for sanctioning (30,058 cases sanctioned each average of 2 days), average time taken (days) to peruse with a view to make a decision to prosecute or not (40 against targeted 30 days), addressing public complaints against DPP staff performance and conduct (meeting the annual of $60 \%$ ) and addressing public complaints against criminal justice processes (60\% against targeted $80 \%$ ), prosecution of 60 against targeted 50 cross border cases among others. Better performance in prosecution of cross-border cases is attributed to cooperation from neighbouring countries during investigations. However the Directorate is unlikely to achieve the annual target opening 5 new DPP stations reportedly awaiting recruitment of State Attorneys.

\section{Uganda Human Rights Commission}

The budget release for the Commission by half annual was UGX5.27bn (54\%) of the approved annual budget of UGX9.7bn and $83 \%$ of the release was spent. The performance assessment shows that the $67 \%$ of the output indicators are likely to be achieved while $33 \%$ are unlikely to be achieved at the current rate of implementation. The efficiency assessment shows that $33 \%$ of output indicators were delivered in line with budget release. Performance assessment indicated that UHRC had already achieved target on circulation of Information, Education and Communication (IEC) materials (36000 out of targeted 2000) by half annual and production and dissemination of know your rights magazines was at $80 \%$ (16000 out of 20000 magazines). However, at current rate of implementation, the Commission is unlikely to achieve the target on training of security agents on different human rights aspects (25\% of 970 agents).

Assessment for annual targets on conclusion of human rights complaints through tribunal, full investigation of cases and monitoring compliance with human rights standards and treaties ratified by Uganda has not done because no targets had been set reportedly as a result of lack of financial allocation under GOU funding. Additional information from the Commission shows that a total of 1,280 files of human rights cases 
Evaluating the Budget \& Efficiency of the Security, Justice \& Governance Cluster in Uganda 51

were investigated, of which 342 files were fully investigated and ready for tribunal proceedings and 938 were partially investigated. The Commission notes that delay in disposal of files is due to uncooperative respondents, failure to obtain evidence such as lock up records from Police, Army and other institutions and loss of contact with complainants after lodging their complaints due to change of address and or loss of interest. In addition, Commission inspected a total of 614 places of detention of which 110 were prisons, 125 police stations, 353 police posts, 5 remand homes and 21 military barracks

\section{Uganda Prisons Services}

The approved annual budget for Uganda Prisons Services (UPS) was UGX 94.33bn and $51 \%$ (UGX46.95bn) of the budget released of which $89 \%$ was spent by the half year. Performance assessment shows that $82 \%$ of the output indicators are likely to be achieved at the current rate of implementation and $18 \%$ may be achieved if additional effort is made. Efficiency assessment showed that $80 \%$ outputs performance is in line with the budget release. At half annual, UPS had already achieved beyond the annual targets on rehabilitation of offenders and provision of prisoners with prison uniform performing at $104 \%$ and $109 \%$ against targets of 8600 and 38533 prisoners respectively. excellent performance in rehabilitation is attributed to intensified rehabilitation programs whereas the performance provision of uniforms is attributed to increase in prisoners population which is the major cost driver of service delivery UPS.

Examples of areas of good progress included: provision of formal education programmes to prisoners (92\% against 2500)-attributed due to increase in the number of units conducting formal education programs to 172 , delivery of prisoners on daily average (957 out of 1491) and creation of more prisons holding capacity by 240 against targeted 350 and this is attributed to support from JLOS towards completion of prisons at Oyam, Amita, reception centres at Pader and Paidha, expansion of Mbarara and remodification of Ndorwa prisons. However, UPS is unlikely to achieve annual targets on construction staff housing units (only 4 staff housing units completed/renovated at Mbarara prison) although the institution reports that most of the staff houses are still undergoing construction for example 28 staff houses at Ruimi, Kiyunga, Muinaina and Kapchorwa. UPS is also unlikely to achieve annual target of surveying prisons land with none of the planned 8 prisons surveyed. This has been attributed to the delay in 
securing GPS machines to survey the land hence the activities were been scheduled for 3rd and 4th quarters of FY2014/15.

\section{Uganda Police Force}

In the first half of the financial year, Uganda Police Force received 50\% (UGX202.74bn) of the annual budget of UGX403.06bn and spent $82 \%$ of the release. Performance assessment of the output indicators show that $82 \%$ of the planned output targets are likely to be achieved at the current rate of implementation while $18 \%$ may be achieved if additional effort is made by the end of the FY2014/15. Efficiency assessment also shows that $82 \%$ of the Institution's output performance was in line with the released funds. Examples of areas that Police Force registered good progress by half annual include: peaceful management of public order incidents (12 out of targeted 20incidents), training of personnel to identify and respond to terrorist incidents (52\% against targeted $77 \%$ ), sensitization and provision of the public with sufficient information and signs of terrorism at $83 \%$, resolution of reported domestic violence cases (51\%), satisfactory handling of complaints against police personnel (69\%), ensuring private security organizations' conformity to standards (100\%) and intensified surveillance measures by the Force to deter entry of international criminals.

With additional effort, the UPF may achieve annual targets on investigation of violent crimes and eventual passing them to DPP for further management (15,576 out of $38,600)$, arrest of suspects using canines (37\% of targeted 3600 ) and improving police to population ratio currently at 1:819 against projected 1:649.

\section{Law Reform Commission}

The approved annual budget for Uganda Law Reform Commission w for FY2014/15 is UGX7.39bn, UGX3.47bn (54\%) was released by half year and UGX3.27bn (88\%) of the release spent. The Commission's performance assessment for the period under review indicates that $33 \%$ of the output indicators are likely to be achieved while $67 \%$ is unlikely to be achieved at the current rate of implementation. Efficiency assessment shows only $17 \%$ of the Commission's output targets were delivered in line with the release of the funds by half annual. Examples of outputs where Commission registered good progress include: compilation of field report under reform and simplification of laws and publication of laws all at $50 \%$ against the target of 2 . However, at the current rate of 
Evaluating the Budget \& Efficiency of the Security, Justice \& Governance Cluster in Uganda 53

implementation, the Commission is unlikely to achieve the target on submission of bills to line ministries, revision of laws, and identification of laws for amendment and translation of laws into local languages which were all at $0 \%$ of their annual targets.

\section{Law Development Centre}

By half annual, Law Development Centre (LDC) had received a total of UGX4.05bn (75\%) against the approved annual budget of UGX5.4bn and all of the released funds were spent by the first half of the financial year. Assessment of output performance shows that the LDC is likely to achieve $50 \%$ of the annual targets at the current rate of implementation; $25 \%$ may be achieved if additional effort is made and another $25 \%$ unlikely to be achieved. The efficiency assessment shows that $13 \%$ of the output indicators were delivered in line with the release of funds.

Performance data indicates that the annual targets set for training of students on Diploma in law and Bar Course had already been achieved scoring 193\% and 135\% against the targets of 350 and 500 students respectively. The performance on Bar Course training was attributed to increase in number of students who passed the preentry examinations. The percentage of students who qualified on Bar Course was $70 \%$ compared to projected $80 \%$ and this has been attributed to dropouts by students who fail exams and those did not meet the fees requirements. The handling of juvenile cases was at $32 \%$ of the targeted 10000 cases hence the Centre may achieve annual target the end of the financial year. However, at the current of implementation, LDC is unlikely to achieve the annual target on petty criminals trained and accepted back in society (50\% against targeted 1000).

\section{Directorate of Citizenship and Immigration Control}

DCIC received UGX78.69bn by the half year against an approved annual budget of UGX119.25bn, and spent UGX66.55bn (85\%) of the release. Assessment of output performance $88 \%$ of the output targets are likely to be achieved while $12 \%$ unlikely to be achieved at the current rate of implementation. Efficiency assessment indicates that $88 \%$ of the output targets were being delivered in line with the released funds. Outputs that registered good progress by half annual include: proportion of passports issued out of 
applications received at $95 \%^{8}$ and each passport issued at average of 10 working days, average number of days taken to issue a work permit improved to 8 days against targeted 10 days (4,840 issued), lead time to clear travellers at 2 minutes and proportion of immigration service delivery points which meet set standards at $28.5 \%$ against targeted $32 \%$ and proportion of cases won against suspected illegal immigrants at $100 \%$. The Directorate is however unlikely to achieve the annual target of issuing $50 \%$ Ugandans who are 18 years and above with National Identity cards as $1 \%$ had been issued. The Directorate notes that 15.6 million people were successfully registered reflecting a $98 \%$ performance and by end of second quarter at least 5 million National ID cards were personalised and printed. However, due to technology and other mobilisation challenges, only 104,000 national ID cards were issued in the pilot phase in Kampala.

\section{Uganda Registration Services Bureau}

URSB's approved budget for FY2014/15 was UGX8.72bn with UGX4.35bn (50\%) released and UGX3.3bn (76\%) of the release spent at half FY. Progressive performance assessment shows that $40 \%$ of output targets is likely to be achieved and another $40 \%$ unlikely to be achieved at the current rate of implementation, while $20 \%$ may be achieved if additional effort is made by the end of FY. Analysis of output performance against the released funds shows that $40 \%$ of the output targets were being delivered in line with the budget release. URSB is likely to achieve the targets on issuance of deaths certificates (54\% and of the targeted 3,000). Performance on births certificates had already achieved the annual targets $(1,222,713$ out of projected 75000 certificates) and this has been attributed to installation of MVRS system in health centres. With additional effort, the Bureau may achieve annual target on registration of trademarks which was at $46 \%$ of the targeted 1,500 trademarks. However, the Bureau is unlikely to meet the annual targets on liquidation of companies and settlement of liabilities-attributed to slow court proceedings, inability by Government to settle its debts due to lack of funds.

\footnotetext{
${ }^{8} 41,765$ passports issued, comprising of 41,434 ordinary passports, 67 official, 147 diplomatic and 117 East African passports.
} 


\section{Legislature}

The focus of the sector is on Making laws for promoting the rule of law, protection of human rights and socio-economic development; Carry out oversight on the Executive; to represent the views of the electorate; to equitably allocate resources and assuring transparency and accountability in the application of public funds, monitoring the implementation of Government programmes and projects (Scrutinizing Government Policy and Administration), debate matters of tropical interest usually highlighted in the President's State of Nation address and vet the appointment of persons nominated by the President under the Constitution.

Parliamentary Commission received UGX167.95bn (51\%) of the approved budget of UGX331.92bn for FY2014/15 and 84\% of the release was spent. Performance analysis shows that $50 \%$ of the output indicators are likely to be achieved while $40 \%$ unlikely to be achieved at the current rate of implementation and $10 \%$ may be achieved with additional effort. The efficiency assessment of the sector shows that $90 \%$ of the output indicators were delivered in line with the fund released and $10 \%$ not delivered in line with the released funds.

Table 1.3: Half-Year Performance Scorecard for Legislature Sector

\section{OUTPUT PERFORMANCE}

\begin{tabular}{|l|c|c|c|c|c|}
\hline & $\begin{array}{c}\text { Likely to be } \\
\text { Achieved }\end{array}$ & May be Achieved & $\begin{array}{c}\text { Unlikely to } \\
\text { be Achieved }\end{array}$ & $\begin{array}{c}\text { No } \\
\text { Assessment }\end{array}$ & Denominator \\
\hline Sector & $50 \%$ & $10 \%$ & $40 \%$ & $0 \%$ & 10 \\
\hline $\begin{array}{l}\text { Parliamentary } \\
\text { Commission }\end{array}$ & $50 \%$ & $10 \%$ & $40 \%$ & $0 \%$ & 10 \\
\hline
\end{tabular}

\section{BUDGET PERFORMANCE}

\begin{tabular}{|l|c|c|c|c|c|c|}
\hline Budget & $\begin{array}{c}\text { Approved } \\
\text { (UGX Bn) }\end{array}$ & $\begin{array}{c}\text { Released } \\
\text { (UGX Bn) }\end{array}$ & $\begin{array}{c}\text { Spent } \\
\text { (UGX } \\
\text { Bn) }\end{array}$ & $\begin{array}{c}\text { \% of } \\
\text { budget } \\
\text { release }\end{array}$ & $\begin{array}{c}\text { \% of } \\
\text { release } \\
\text { spent }\end{array}$ & $\begin{array}{c}\% \text { of } \\
\text { budget } \\
\text { spent }\end{array}$ \\
\hline Sector Total & 331.92 & 167.95 & 140.25 & $51 \%$ & $84 \%$ & $42 \%$ \\
\hline $\begin{array}{l}\text { Parliamentary } \\
\text { Commission }\end{array}$ & 331.92 & 167.95 & 140.25 & $51 \%$ & $84 \%$ & $42 \%$ \\
\hline
\end{tabular}




\section{EFFICIENCY ASSESSMENT}

\begin{tabular}{|l|c|c|c|c|}
\hline & $\begin{array}{c}\text { \% where output } \\
\text { performance is in } \\
\text { line with budget } \\
\text { released }\end{array}$ & $\begin{array}{c}\text { \% where output } \\
\text { performance is not in } \\
\text { line with budget } \\
\text { released }\end{array}$ & $\begin{array}{c}\text { No } \\
\text { Assessment }\end{array}$ & Denominator \\
\hline Sector Total & $90 \%$ & $10 \%$ & $0 \%$ & 10 \\
\hline $\begin{array}{l}\text { Parliamentary } \\
\text { Commission }\end{array}$ & $90 \%$ & $10 \%$ & $0 \%$ & 10 \\
\hline
\end{tabular}

*Where progress in performance indicators were proportional to financial releases at output level, in cases where progress in performance indicator was equal or above the releases.

\section{Parliament}

In the first-half of the FY 2014/15, Parliament registered good progress in passing of bills where $14(58 \%)$ bills were passed out of the planned 24, 34 (65\%) Ministerial and other Statements have been presented by mid FY2014/15 against a target of 52 this being attributed to by the high level of vigilance of Legislators on the Executive. Because of this, the sector reported that the target is expected to shoot come next financial year. $26(57 \%)$ Committee reports have been produced and considered by plenary at the same point in time in FY2014/15 against a set target of 46 and 558(90\%) Committee meetings have been held out of the 620 that were planned for FY2014/15 and this has been attributed to the fact that a lot of business is currently being handled by Committees. However more efforts are required in the conducting of oversight field trips in order for the sector to achieve their annual target of 150 field trips by end of the year. Slow progress was registered in the answering of questions, passing of motions, Disposing of petitions and carrying out of outreach programmes. The Sector further indicated that only two motions were presented to plenary but have not yet been debated, 8 petitions have also been presented though the Committees have not had time to dispose then off. No outreach programme has been carried out due to lack of funds since the activity has been donor funded. However efforts are underway to mainstream this particular activity. 
Evaluating the Budget \& Efficiency of the Security, Justice \& Governance Cluster in Uganda 57

\section{Public Administration Sector}

The key objectives of the sector are to: facilitate the Presidency in fulfilling its constitutional mandate, promote and manage commercial diplomacy, regional and international relations; strengthen policy development and management across Government, monitor Government policies, programs and projects, conduct regular free and fair elections and referenda. The sector is led by the Office of the President (OP), and includes State House, Ministry of Foreign Affairs (MoFA) and Electoral Commission (EC).

By half of the FY2014/15, the sector had received UGX246.04bn (54\%) of the approved annual budget of UGX459.27bn and spent 70\% (UGX173.03bn) of the release. Assessment of the sector output indicators targets show that $77 \%$ of the indicators are likely to be achieved a decline from the $84 \%$ at the same point in time for FY2013/14 and $10 \%$ unlikely to be achieved at current rate of implementation while $10 \%$ may be achieved with additional effort. Efficiency assessment shows that only $57 \%$ of the sector output targets were delivered in line with the release.

Table 1.4: Half-Year Performance Scorecard for Public Administration Sector

\section{OUTPUT PERFORMANCE}

\begin{tabular}{|l|c|c|c|c|c|}
\hline & $\begin{array}{c}\text { Likely to } \\
\text { be } \\
\text { Achieved }\end{array}$ & $\begin{array}{c}\text { May be } \\
\text { Achieved }\end{array}$ & $\begin{array}{c}\text { Unlikely } \\
\text { to be } \\
\text { Achieved }\end{array}$ & $\begin{array}{c}\text { No } \\
\text { Assessment }\end{array}$ & Denominator \\
\hline Sector & $\mathbf{7 7 \%}$ & $\mathbf{1 0 \%}$ & $\mathbf{1 0 \%}$ & $\mathbf{3 \%}$ & $\mathbf{3 0}$ \\
\hline Office of the President & $78 \%$ & $0 \%$ & $11 \%$ & $11 \%$ & 9 \\
\hline Ministry of Foreign Affairs & $100 \%$ & $0 \%$ & $0 \%$ & $0 \%$ & 10 \\
\hline Electoral Commission & $43 \%$ & $29 \%$ & $28 \%$ & $0 \%$ & 7 \\
\hline State House & $75 \%$ & $25 \%$ & $0 \%$ & $0 \%$ & 4 \\
\hline
\end{tabular}

BUDGET PERFORMANCE

\begin{tabular}{|l|c|c|c|c|c|c|}
\hline Budget & $\begin{array}{c}\text { Approved } \\
\text { (UGX Bn) }\end{array}$ & $\begin{array}{c}\text { Released } \\
\text { (UGX Bn) }\end{array}$ & $\begin{array}{c}\text { Spent } \\
\text { (UGX Bn) }\end{array}$ & $\begin{array}{c}\% \text { of } \\
\text { budget } \\
\text { release }\end{array}$ & $\begin{array}{c}\text { \% of } \\
\text { release } \\
\text { spent }\end{array}$ & $\begin{array}{c}\% \text { of } \\
\text { budget } \\
\text { spent }\end{array}$ \\
\hline Sector Total & 459.27 & 246.04 & 173.03 & $54 \%$ & $70 \%$ & $38 \%$ \\
\hline Office of the President & 38.94 & 18.13 & 16.11 & $47 \%$ & $89 \%$ & $41 \%$ \\
\hline Ministry of Foreign Affairs & 19.905 & 11.147 & 10.25 & $56 \%$ & $92 \%$ & $51 \%$ \\
\hline State House & 249.84 & 114.19 & 131.94 & $58 \%$ & $92 \%$ & $53 \%$ \\
\hline
\end{tabular}




\begin{tabular}{|l|c|c|c|c|c|c|}
\hline Budget & $\begin{array}{c}\text { Approved } \\
\text { (UGX Bn) }\end{array}$ & $\begin{array}{c}\text { Released } \\
\text { (UGX Bn) }\end{array}$ & $\begin{array}{c}\text { Spent } \\
\text { (UGX Bn) }\end{array}$ & $\begin{array}{c}\% \text { of } \\
\text { budget } \\
\text { release }\end{array}$ & $\begin{array}{c}\% \text { of } \\
\text { release } \\
\text { spent }\end{array}$ & $\begin{array}{c}\% \text { of } \\
\text { budget } \\
\text { spent }\end{array}$ \\
\hline Electoral Commission & 150.58 & 72.57 & 14.73 & $56 \%$ & $20 \%$ & $10 \%$ \\
\hline
\end{tabular}

\section{EFFICIENCY ASSESSMENT}

\begin{tabular}{|l|c|c|c|c|}
\hline & $\begin{array}{c}\text { \% where output } \\
\text { performance is in } \\
\text { line with budget } \\
\text { released }\end{array}$ & $\begin{array}{c}\text { \% where output } \\
\text { performance is } \\
\text { not in line with } \\
\text { budget released }\end{array}$ & $\begin{array}{c}\text { No } \\
\text { Assessment }\end{array}$ & Denominator \\
\hline Sector Total & $57 \%$ & $43 \%$ & $0 \%$ & 30 \\
\hline Office of the President & $67 \%$ & $33 \%$ & $0 \%$ & 9 \\
\hline Ministry of Foreign Affairs & $100 \%$ & $0 \%$ & $0 \%$ & 10 \\
\hline Electoral Commission & $14 \%$ & $86 \%$ & $0 \%$ & 7 \\
\hline State House & $0 \%$ & $100 \%$ & $0 \%$ & 4 \\
\hline
\end{tabular}

\section{Office of the President}

The budget release for the Office of the President by half year was UGX18.13bn (47\%) of the approved annual budget of UGX38.94bn and $89 \%$ of the release was spent. The performance indicator assessment shows that $78 \%$ of the output indicators targets are likely to be achieved while $11 \%$ unlikely to be achieved at the current rate of implementation. The efficiency assessment shows that $67 \%$ of output indicators were delivered in line with budget release and $33 \%$ of the output indicators not delivered in line with the budget release.

The assessment also indicates that Office of the President has already achieved its targets on following up activities: identification of issues from monitoring exercises, for which 11 irrigation schemes, 26 valley dams and 7 valley tanks were monitored in 17 districts across the country. Data from the sector further indicates that 24 Hydro Power Energy Projects were also monitored in the following districts: Kabale, Kasese, Kanungu, Rukungiri Kamwenge Buikwe, Jinja, Kamuli, Bukwo, Hoima, Masindi, Kiryandongo, Moyo, Yumbe, Zombo, and Nwoya. The institution has also taken an average of 5 (160\%) days to scrutinise cabinet submissions compared to the 8 days that had been targeted for in FY2014/15. 
Evaluating the Budget \& Efficiency of the Security, Justice \& Governance Cluster in Uganda 59

Good progress in performance has also been registered in the number of the RDCs meeting agreed objectives $80 \%$ against the annual target of $100 \%$ : (i) $2(50 \%)$ of the public programmes/projects inspected out of the planned 4 and (ii) 2(50\%) tracking reports produced against the 4 that were planned for. However, the Institution may not achieve its targets on the number of annual manifesto handbooks distributed to MDAs and this has been attributed to the fact that these handbooks are only given out towards the end of the year.

\section{State House}

By half year, State House had received 58\% (UGX 144.19bn) of the annual budget of 249.84Bn and spent UGX131.94bn (92\%) of the release. Assessment of the outputs performance indicates a good progress performance at $75 \%$ of the indicators targets likely to be achieved at the current rate of implementation. However, outputs performance vis-à-vis spending shows that State House has $100 \%$ of its outputs not delivered in line with the released funds. The good progress in performance was realized in the following indicators: attending regional and international meetings $15(75 \%)$ of the targeted 20 , and attending International Trade meetings 5(63\%) of the targeted 8 meetings. Data from the institution further indicates that $95 \%$ of the demands received on logistical support for the welfare and security of the President were met, 498 programmes have been facilitated, 14 new investments have been commissioned and 39 Hospitals and 195 health Centres have been monitored.

\section{Ministry of Foreign Affairs}

Ministry of Foreign Affairs by half year had received UGX11.15bn (56\%) against an approved budget of UGX19.90bn and spent 92\% (UGX 10.26bn) of the release. Output performance assessment indicates that all the indicators are likely to be achieved at the current rate of implementation by the end of financial year and efficiency assessment also indicates that $100 \%$ of the output indicators were delivered in line with the budget release.

By half year, the Ministry had held all the planned bilateral engagements, where 4 agreements in infrastructure development and investment were signed with Kenya, Rwanda, and South Sudan at the Northern corridor summit in Kigali and the Kampala summit. One MoU signed with the Republic of Korea in education promotion but 1 grant 
agreement with Japan JPC in collaboration with South Sudan Government was postponed due to conflict.

Data from the sector further indicates that 3(50\%) multilateral engagements were held, where 1 conference (NCIP) was held to promote Uganda's interests in the region. The Ministry also participated in the $29^{\text {th }}$ EAC Session of the Council of Ministers, participated in the $2^{\text {nd }}$ extra ordinary Joint meeting of the sectoral councils on cooperation in defence and coordinated Interstate Security and Foreign Policy with in EAC.

Ministry of Foreign Affairs also has facilitated 12(92\%) of the planned 13 Presidential and VIP visits, held 3(60\%) tourism promotional engagements out of the planned 5, and this was done through coordinating the Uganda-Rwanda Business Forum for tourism promotion, holding an investment promotion conference in Rome where Uganda was marketed as a tourist destination and participating in a tourism exhibition in Tokyo. In addition the Ministry also facilitated 13(87\%) diplomatic meetings against a target of 15 where meetings were coordinated and facilitated between H.E the president, senior Government officials and members of the diplomatic corps (Ambassadors of South Korea, Sri Lanka, Germany, Ireland, Brazil, Botswana, DPRK, India, Vatican, China, UAE, Kenya and Sri Lanka) and held 3(60\%) trade promotional engagements against the 5 that were planned for FY 2014/15.

The Ministry further indicates that $109(52 \%)$ scholarships have been secured by half year out of the planned 210 and these are; 41 scholarships from India, 23 from Singapore, 7 from South Korea, 12 from Malaysia, 3 from Mauritius and 23 from Egypt. 21 reported cases of mistreated Ugandans have been handled out of 30 reported cases: 9 cases in UAE, 2 in Malaysia, 3 in China, 2 in Germany, 1 in Geneva, 1 in Ethiopia, 1 in Saudi Arabia, 1 in India and 1 in Afghanistan.

\section{Electoral Commission}

Electoral Commission received 48.2\% (UGX72.57bn) of the annual budget of UGX150.58bn and spent only UGX14.73bn (20.3\%) of the release. Assessment indicates that only $43 \%$ of the Commission's output indicators targets are likely to be achieved and $29 \%$ unlikely to be achieved at the current rate of implementation and $29 \%$ of the indicators may be achieved if additional effort is made. Efficiency analysis at half annual shows that only $14 \%$ of output indicators were delivered in line with release. At half 
Evaluating the Budget \& Efficiency of the Security, Justice \& Governance Cluster in Uganda 61

annual the commission has already achieved its annual target of concluding all the reported complaints / petitions that came from the public by half year.

In the first-half of the FY 2014/15, Electoral Commission registered good progress in; assessing the proportion of the public that had received information on electoral processes understood and retained that knowledge 50(71\%) against the target of 70 and proportion of stakeholders participating in voter education and training performing at $60 \%$ of the planned $90 \%$ in FY2014/15. However more efforts are required in the implementation of stake holder recommendations arising from consultative meetings if the institution is to achieve its annual target of 50 by end of the financial year. Slow progress was registered in ensuring all eligible voters are listed in the voter register and filling vacancies at all levels where only 1 (25\%) vacancy was filled against a target of 4 .

\section{The Public Sector Management Sector}

The medium term objectives of the Public Sector Management (PSM) Sector focus on establishing mechanisms that will enhance coordination, monitoring and evaluation of Government policies and programmes, promote coordinated and harmonized policy planning and budgeting at National and Local Governments levels. Besides, it focuses on attracting, recruiting, developing and retaining highly skilled and professional workforce, managing decentralized service delivery systems and promoting the integration of Partner States into the East African Community. PSM is led by the Office of the Prime Minister and includes the Ministry of East African Community Affairs, Local Government Finance Commission, Ministry of Local Government, Ministry of Public Service, Public Service Commission, National Planning Authority and Kampala Capital City Authority.

The PSM Sector had a total annual budget of UGX 847.407bn out of which $50 \%$ (UGX $425.476 \mathrm{bn}$ ) was released and $90 \%$ of the release (UGX $384.923 \mathrm{bn}$ ) was spent. With this budget, $55 \%$ of the Sector's output indicators are likely to be achieved at current rate of implementation, $8 \%$ may be achieved with additional effort, while $14 \%$ of the output indicators are unlikely to be achieved at the current rate of implementation by the end of the financial year. The remaining $23 \%$ of the output indicators had no sufficient data for assessment. The Sector achieved this performance level with $45 \%$ of the annual budget spent. Within the sector, some MDAs are likely to deliver on their outputs by the end of the financial year. However, Local Government Finance Commission and Ministry 
of Public Service are unlikely to meet all their targets by close of the financial year at the current rate of implementation.

The efficiency assessment looks at delivery level on output targets and budget release for each output. The basis of assessing efficiency, or utilization of resources, judges the delivery performance against the level of the release. 54\% of the Sector delivery on its output indicators targets is in line with the budget released at half year stage budget while $46 \%$ of output indicators were not in line with budget released. A case in point is Ministry of East African Community Affairs (MEACA). MEACA achieved $20 \%$ performance on output indicators by mid-year however, considering that $87 \%$ of the Ministry's budget was released and $98 \%$ of the budget was spent by mid-year; the delivery on output indicators was at $67 \%$ indicating that delivery on output indicators was not in line with release.

Table 1.5: Half-Year Performance Scorecard for Public Sector Management sector

\section{OUTPUT PERFORMANCE}

\begin{tabular}{|c|c|c|c|c|c|}
\hline & $\begin{array}{l}\text { Likely to be } \\
\text { Achieved }\end{array}$ & $\begin{array}{c}\text { May be } \\
\text { Achieved }\end{array}$ & $\begin{array}{l}\text { Unlikely to be } \\
\text { Achieved }\end{array}$ & $\begin{array}{c}\text { No } \\
\text { Assessment }\end{array}$ & Denominator \\
\hline Sector & $55 \%$ & $8 \%$ & $14 \%$ & $23 \%$ & 130 \\
\hline OPM & $82 \%$ & $4 \%$ & $14 \%$ & $0 \%$ & 29 \\
\hline LGFC & $20 \%$ & $30 \%$ & $50 \%$ & $0 \%$ & 5 \\
\hline NPA & $67 \%$ & $0 \%$ & $33 \%$ & $0 \%$ & 3 \\
\hline PSC & $17 \%$ & $16 \%$ & $0 \%$ & $67 \%$ & 5 \\
\hline MoLG & $86 \%$ & $5 \%$ & $0 \%$ & $9 \%$ & 8 \\
\hline MEACA & $20 \%$ & $20 \%$ & $50 \%$ & $10 \%$ & 10 \\
\hline MoPS & $86 \%$ & $0 \%$ & $0 \%$ & $14 \%$ & 11 \\
\hline KCCA & $35 \%$ & $7 \%$ & $7 \%$ & $51 \%$ & 59 \\
\hline
\end{tabular}

\section{BUDGET PERFORMANCE}

\begin{tabular}{|l|c|c|c|c|c|c|}
\hline Budget & $\begin{array}{c}\text { Approved } \\
\text { (UGX Bn) }\end{array}$ & $\begin{array}{c}\text { Released } \\
\text { (UGX Bn) }\end{array}$ & $\begin{array}{c}\text { Spent } \\
\text { (UGX Bn) }\end{array}$ & $\begin{array}{c}\% \text { of } \\
\text { budget } \\
\text { release }\end{array}$ & $\begin{array}{c}\% \text { of } \\
\text { release } \\
\text { spent }\end{array}$ & $\begin{array}{c}\% \text { of } \\
\text { budget } \\
\text { spent }\end{array}$ \\
\hline $\begin{array}{l}\text { Sector Total } \\
\text { (GOU+Donor) }\end{array}$ & 945.32 & 409.54 & 367.44 & $43 \%$ & $90 \%$ & $39 \%$ \\
\hline
\end{tabular}


Evaluating the Budget \& Efficiency of the Security, Justice \& Governance Cluster in Uganda 63

\begin{tabular}{|c|c|c|c|c|c|c|}
\hline Budget & $\begin{array}{l}\text { Approved } \\
\text { (UGX Bn) }\end{array}$ & $\begin{array}{l}\text { Released } \\
\text { (UGX Bn) }\end{array}$ & $\begin{array}{c}\text { Spent } \\
\text { (UGX Bn) }\end{array}$ & $\begin{array}{c}\% \text { of } \\
\text { budget } \\
\text { release }\end{array}$ & $\begin{array}{c}\% \text { of } \\
\text { release } \\
\text { spent }\end{array}$ & $\begin{array}{c}\% \text { of } \\
\text { budget } \\
\text { spent }\end{array}$ \\
\hline $\begin{array}{l}\text { Sector Total } \\
\text { (GOU) }\end{array}$ & 762.864 & 366.658 & 325.025 & $48.1 \%$ & $89 \%$ & $43 \%$ \\
\hline $\begin{array}{l}\text { OPM } \\
\text { (GOU+Donor) }\end{array}$ & 188.418 & 111.442 & 91469 & $54 \%$ & $39 \%$ & $72 \%$ \\
\hline OPM (GOU) & 127.586 & 68.651 & 69.057 & $60 \%$ & $48 \%$ & $82 \%$ \\
\hline $\begin{array}{l}\text { LGFC } \\
\text { (GOU+Donor) }\end{array}$ & 4.529 & 2.266 & 2.100 & $54 \%$ & $46 \%$ & $46 \%$ \\
\hline LGFC (GOU) & 4.529 & 2.266 & 221.62 & $50 \%$ & $47 \%$ & $93 \%$ \\
\hline $\begin{array}{l}\text { NPA } \\
\text { (GOU+Donor) }\end{array}$ & 14.614 & 8.076 & 8.008 & $55 \%$ & $59 \%$ & $99 \%$ \\
\hline NPA (GOU) & 14.614 & 8.076 & 8.008 & $55 \%$ & $59 \%$ & $99 \%$ \\
\hline $\begin{array}{l}\text { PSC } \\
\text { (GOU+Donor) }\end{array}$ & 4.936 & 2.519 & 2.477 & $51 \%$ & $50 \%$ & $98 \%$ \\
\hline PSC (GOU) & 4.936 & 2.519 & 2.477 & $51 \%$ & $50 \%$ & $98 \%$ \\
\hline $\begin{array}{l}\text { MoLG } \\
\text { (GOU+Donor) }\end{array}$ & 28.579 & 12.420 & 11.162 & $43 \%$ & $39 \%$ & $90 \%$ \\
\hline MoLG (GOU) & 220.190 & 12.420 & 11.162 & $5.6 \%$ & $5 \%$ & $90 \%$ \\
\hline $\begin{array}{l}\text { MEACA } \\
\text { (GOU+Donor) }\end{array}$ & 20.247 & 17.692 & 17.416 & $87 \%$ & $86 \%$ & $98 \%$ \\
\hline MEACA (GOU) & 20.247 & 17.692 & 17.416 & $87 \%$ & $86 \%$ & $98 \%$ \\
\hline $\begin{array}{l}\text { MoPS } \\
\text { (GOU+Donor) }\end{array}$ & 306.653 & 137.915 & 131.404 & $45 \%$ & $43 \%$ & $95 \%$ \\
\hline MoPS (GOU) & 306.653 & 137.915 & 131.404 & $45 \%$ & $43 \%$ & $95 \%$ \\
\hline $\begin{array}{l}\text { KCCA } \\
\text { (GOU+Donor)* }\end{array}$ & 255.72 & 117.209 & 103.401 & $\begin{array}{c}45.83 \\
\%\end{array}$ & $88.22 \%$ & $\begin{array}{c}40.44 \\
\%\end{array}$ \\
\hline KCCA (GOU)* & 255.72 & 117.209 & 103.401 & $\begin{array}{c}45.83 \\
\%\end{array}$ & $88.22 \%$ & $\begin{array}{c}40.44 \\
\%\end{array}$ \\
\hline
\end{tabular}

\section{EFFICIENCY ASSESSMENT}

\begin{tabular}{|l|c|c|c|c|}
\hline & $\begin{array}{c}\text { \% where output } \\
\text { performance is in line } \\
\text { with budget } \\
\text { released** }\end{array}$ & $\begin{array}{c}\text { \% where output } \\
\text { performance is not in } \\
\text { line with budget released }\end{array}$ & $\begin{array}{c}\text { No } \\
\text { Assessment }\end{array}$ & Denominator \\
\hline $\begin{array}{l}\text { Sector } \\
\text { Total }\end{array}$ & $48 \%$ & $48 \%$ & $14 \%$ & 130 \\
\hline OPM & 38 & $62 \%$ & $0 \%$ & 29 \\
\hline LGFC & $20 \%$ & $80 \%$ & $0 \%$ & 5 \\
\hline
\end{tabular}




\begin{tabular}{|l|c|c|c|c|}
\hline NPA & $33 \%$ & $67 \%$ & $0 \%$ & $\mathbf{3}$ \\
\hline PSC & $17 \%$ & $50 \%$ & $33 \%$ & $\mathbf{5}$ \\
\hline MoLG & $90 \%$ & $10 \%$ & $0 \%$ & $\mathbf{8}$ \\
\hline MEACA & $33 \%$ & $67 \%$ & $0 \%$ & $\mathbf{9}$ \\
\hline MoPS & $43 \%$ & $43 \%$ & $14 \%$ & $\mathbf{7}$ \\
\hline KCCA & $\#$ & $\#$ & $\# \%$ & $\#$ \\
\hline
\end{tabular}

*Budget added from the sector reports.

** Where progress performance indicators were proportional to financial releases at output level, in cases where progress in performance indicator was equal or above the releases.

\section{Office of the Prime Minister}

The Office of the Prime Minister (OPM) received a total of UGX 111.418 out of the budget of $188.41 \mathrm{bn}$ and spent 39\% (UGX91.469) of the release. By mid-year $82 \%$ of output indicators are likely to be achieved at the current rate of implementation, $4 \%$ of the output indicators may be achieved with more effort, $14 \%$ are unlikely to be achieved at the current rate of implementation. The budget efficiency assessment shows that the output performance dropped to $54 \%$ against $80 \%$ of UGX111.442Bn budget released. This indicates that delivery on the output targets is not in line with the funds released. This could mean that the sector may be setting soft target. Under the output on Government Policy Implementation Coordination, out of the 16 planned, cross/intersectoral issues 8 were resolved through the coordination framework arrangement. Thus $50 \%$ of the output indicators is likely to be achieved and the delivery of the output so far is in line with the budget release.

By half year, under the output on Functioning National Monitoring and Evaluation, the Government Annual Performance Report (GAPR) FY 2013/14 was produced and discussed at the Retreat of Cabinet Ministers, Ministers of State, Permanent Secretaries and LGs in January 2014. Of the planned 2 professional and credible evaluations one was delivered; this is target likely to be achieved at the end of the FY. The implementation of the Citizen's Demand for Accountability (Baraza) initiative had been conducted in twenty four districts ${ }^{9}$. In addition, all three output targets are likely to be achieved at the end of the FY and are in line with the budget released.

\footnotetext{
${ }^{9}$ Rukungiri, Kalangala, Sironko, Moroto, Napak, Kaabong, Kotido, Abim, Nakapiripirit, Amudat, Adjumani, Ntungamo, Mayuge, Kaliro, Kyankwanzi, Kamuli, Buyende, Namutumba, Butambala, Nakaseke, Mityana, Lyantonde, Kasese, Rubirizi districts. Funds for Ibanda and Kiruhura District Barazas were committed but the activities pushed to $3^{\text {rd }}$ quarter.
} 
Evaluating the Budget \& Efficiency of the Security, Justice \& Governance Cluster in Uganda 65

Under Coordination of Government business in Parliament all the three output indicators are likely to be achieved by the close of the FY and their performance was in line with budget released at half year period. Six (50\%) of the planned 12 reports of Government business in Parliament were produced; 50 (50\%) of the planned 100 disposal rate of bills to Parliament that are enacted into law within the stipulated period of time was achieved. The percentage attendance of Minister in Parliament for key session was $70 \%$ of the planned $100 \%$

Under output on Effective Preparedness and Response to Disasters; 20 risk and vulnerability assessments were conducted by half year against the annual target of 30 , the average response time to disasters was 44 hours, faster than the planned 72 hours. Both output indicators are likely to be met by the end of the FY. Whereas 12 District Disaster Management Committees were established and trained against 25 districts, the target may be met with more effort at the current rate of implementation. Under the output of Relief to Disaster Victims, by half-year; 910,000 disaster victims were supplied with food and non-food items out of the 200,000 half annual target. Both output indicators performance under the Granting of asylum and repatriation refugees were in line with the percentage budget released and are likely to be achieved at the current rate of implementation. 10,334 refugees' asylum claims were processed against the annual target of 10,000 , while 3,827 refugee identification documents were processed of the planned 5,000.

By half year the coordination and monitoring of the implementation of Peace Recovery and Development Programme (PRDP) had achieved 50\% of all the output indicators. 6 of the 12 planned PRDP coordination meetings were held; two of the planned four monitoring reports were produced, while $50 \%$ of the planned actions from PMC meetings were implemented. While these three output indicators are likely to be achieved at the close of the FY2014-15, the delivery of the output indicator targets were not in line with the budget released.

The coordination of the implementation of Luwero-Rwenzori Development Programme (LRDP) had achieved up to more than $50 \%$ of the annual target by $31^{\text {st }}$ December 2014. The $1^{\text {st }}$ report of the two planned performance monitoring reports had been produced, 35 of the 60 planned household income enhancing micro projects had been supported and the Annual consolidated district performance report had been produced. 5,178 civilian veterans (207.1\%) were paid a one-off gratuity, a number twice 
the planned target 2,500. Also the two quarterly coordination meetings for civilian veterans had been held. The output targets for the payment of gratuity and coordination of war debts' clearance were both likely to be achieved. Under the output on Coordination of the implementation of Karamoja Integrated Development Programme (KIDP), with $63.4 \%$ (UGX1.41bn) of the approved budget released UGX1.34bn had been spent by mid-year; all the indicators are likely to be already achieved. 6 of the 12 planned KIDP coordination meetings were held; two of the planned four monitoring reports were produced, while $50 \%$ of the planned actions from KPC meetings were implemented.

\section{Local Government Finance Commission}

The Local Government Finance Commission (LGCF) received UGX 2.266bn (55\%) of the approved budget of which UGX2.106bn $46 \%$ was spent. $20 \%$ of the output indicator targets are likely to be achieved at the current rate of implementation, $30 \%$ of the output targets maybe achieved with more effort at the present rate of implementation, while the remaining $50 \%$ are unlikely to be achieved at the current rate of implementation. Delivery performance against release remains the same at $20 \%$ against $80 \%$ of UGX $2.266 \mathrm{bn}$ budget released; inferring that delivery on the output targets is slower than release.

Under the output on Local Government (LG) budgets analysis ${ }^{10}$; by end of the second quarter, 9 of the planned 20 Local Governments were provided with skills in the budgets formulation, this is attributed to delayed submission of approved budgets by Local Governments which was caused by updating of the OBT tool by MoFPED. Of the 60 days planned average length of time taken to provide feedback on analysed budgets no feedback was made. At the same time, of the planned 40 number of Local Governments complying with budgeting legal requirement none complied. Therefore the three indicators targets are unlikely to be achieved and as a result the output may not be delivered by the end of the FY. In addition the performance of the three indicators is not in line with the budget release. The Commission further reported that the LG budget analysis is expected to start in the third quarter.

\footnotetext{
${ }^{10}$ This involves checking for compliance with budgetary guidelines and taking into account sector priorities and issues.
} 
Evaluating the Budget \& Efficiency of the Security, Justice \& Governance Cluster in Uganda 67

Under the output on enhancement of LG revenue mobilisation and generation; 20 of the planned 58 LGs were applying best practices ${ }^{11}$ therefore the target may be achieved at the end of the financial year with more effort. At the same time, the number of LGs provided with skills to establish Local revenue data base, was 14 out of the planned 36. The target may be achieved at the end of the FY with more effort at the current rate of implementation. Zero out of the planned two percentage change in annual local revenue performance $(\mathrm{MC})$ was recorded by half year. However no reason is given for the dismal performance of the said indicators. However 16 out of the planned 22 number of LGs were provided with skills in the collection of property rates and there output indicator target is likely to be achieved at the end of the FY and it is also in line with the budget released.

\section{National Planning Authority (NPA)}

The Authority received a total of UGX8.076 (55\%) of the approved budget of UGX14.416 bn and spent UGX8.008bn (59\%) of the release. $67 \%$ of the output indicators are likely to be achieved at the current rate of implementation, 33\% of the output targets are unlikely to be achieved at the current rate of implementation. In regard to budget efficiency, the Authority delivered $67 \%$ of their output indicators against $55 \%$ of the budget released and $99 \%$ of releases spent implying that delivery is in line with releases. On the output Functional Planning Systems and Frameworks/Plans: 134 (105\%) of the planned 128 of the institutions (MDAs and LGs) supported in development planning By mid-year, the Authority developed background paper on strategic direction and macroeconomic framework for NDPII (2015/16-2019/20); and collected data towards the production of national spatial plan for illustration in the Plan. However under the output Functional think tank, of the 8 planned PEC/researched papers only one researched paper was produced by half year ${ }^{12}$.

\footnotetext{
${ }^{11}$ This involves checking whether LGs are complying with the criteria during revenue collection. This is done mainly to enhance revenue collection for example by putting in place an incentive framework for people collecting revenue.

${ }^{12}$ Scaling up Value Addition in Agricultural Products, Curbing Corruption to Improve Service Delivery and Enhancing Uganda's Tourism Sector for Growth and Employment.
} 


\section{Public Service Commission}

Out of the approved annual budget of 9.936bn the Public Service Commission (PSC) received a total of UGX 2.519bn (51\%) and spent 50\% (UGX 2.519bn) of the release. 16\% of output indicators are likely to be achieved at the current rate of implementation, while $17 \%$ of the output targets may be achieved by the close of the year with additional effort. With $50 \%$ of UGX $2.519 \mathrm{bn}$ budget released; output performance moved down to $17 \%$ implying delivery is below release level. By half year, the Commission reported 0 of 30 District Service Commissions (DSCs) ${ }^{13}$ were not provided with technical assistance and capacity gaps 17 out of the targeted 25 competence based selections instruments ${ }^{14}$ were developed by mid-year showing that the target is likely to be achieved at the current rate of implementation. Furthermore, 3500 of the targeted 1,455 vacancies were filled by mid-year and 1,455 of recruitment submissions were handled and concluded against that target of 3,500 by mid-year. This shows that the target maybe met by the end of the financial year.

\section{Ministry of Local Government}

Ministry of Local Government (MoLG) received a release of UGX $12.420 \mathrm{bn}$ (5.6\%) of the approved budget of UGX 220.190 and spent 5\% (UGX11.162bn). 86\% of the Ministry's output indicators are likely to be achieved at the current rate of implementation, $5 \%$ may be achieved at the end of the FY with additional effort. The Ministry's performance in regard to output targets achieved compared to budget released by mid-year was $90 \%$ implying that delivery on output targets is ahead of budget release.

Under Monitoring and Support Supervision of Local Governments output, 87\% of Local Governments have functional Technical Planning Committees (TPCs), Public Accounts Committees (PACs), District Service Commissions (DSCs), Land Boards and Contracts Committees out of the targeted $100 \%$ Local Governments. This target is likely

\footnotetext{
${ }^{13}$ DSC monitoring visits carried out in the districts of Kole, Oyam, Kitgum, Pader, Agago, Otuke, Dokolo and Amolatar. Reviewed previous reports and carried out performance audit for the DSCs of Serere, Kaberamaido, Kibuku, Gombe, Rakai and Lwengo.

14 Developed Selection Instruments for the following Districts/Agencies/Ministries:- Districts: Amolator, Kisoro, Kabale, Kanugu, Arua, Wakiso. Agencies: Parliament of Uganda, NITA-U, EOC, OAG, UBOS. Ministries: office of the president, Water and environment, Local Government, Agriculture animal industry \& fisheries, Public Service, East African Community, Justice \& Constitutional affairs, MFPED, Gender labour \& social development.
} 
Evaluating the Budget \& Efficiency of the Security, Justice \& Governance Cluster in Uganda 69

to be achieved at the current rate of implementation. The indicator target under output 131201 on LG Councillors trained was achieved by mid-year stage with $5.6 \%$ of UGX $12.420 \mathrm{bn}$ budget release. All the output indicators under the output on strengthening financial management and accountability in LGs are likely to be achieved by year end at the current rate of implementation. Under the output in inspection and monitoring of LGs, 56 out of the targeted 111 LGs were covered by routine inspection, which means that by end of the FY the target may be achieved with added effort. The indicator target under the output is likely to be achieved by close of the FY at the present rate of implementation.

\section{Ministry of East African Community Affairs}

The Ministry of East African Community Affairs (MEACA) received a release of UGX17.692bn (87\%) and of the approved budget of UGX 20.247bn. By half year, $86 \%$ of the release (UGX 17.416 bn) had been spent. The Ministry exhibited poor progress in delivery on its output targets with $20 \%$ of the output indicators likely to be achieved at the current rate of implementation while $20 \%$ of the output indicators maybe achieved if additional effort is made and the remaining 50\% targets are unlikely to be achieved at the present rate of implementation. Considering budget efficiency assessment against set targets; delivery on output indicators dropped to $33 \%$ against $67 \%$ of the UGX $17.692 \mathrm{bn}$ budget released, signifying that delivery is slower than the release level.

By the end of the second quarter, out of the planned 18 Country position papers and back to office reports on the EAC regional meetings, 5 had been prepared ${ }^{15}$ and 1 Cabinet memo ${ }^{16}$ was drafted and submitted.

\footnotetext{
${ }^{15}$ The position papers are: 1 . Country position paper for the $27^{\text {th }}$ meeting of the EAC Council of Ministers

2. Country position paper for the $28^{\text {th }}$ meeting of the EAC Council of Ministers, 3 . Country position paper for the meeting of the Sectoral Council on Agriculture \& Food security meeting, 4. Country position paper for the meeting of the Sectoral Council on Lake Victoria Basin Commission(LVBC) meeting, 5. Country position paper for the meeting of the Sectoral Council on Ministers responsible for EAC Affairs \& Planning, 6. Country position paper for the meeting of the Sectoral Council on Transport Communication \& Meteorology, 7. Country position paper for the meeting of the Sectoral Council on Economic Affairs, 8. Country position paper for the meeting of the EAC Finance \& Administration Committee.

16 1. Cabinet on $14^{\text {th }}$ August 2013 ratified the EAC Protocol on establishment of the East African Kiswahili Commission and therefore authorized the Minister of foreign Affairs to deposit the
} 
All the indicators under the output on the monitoring and evaluation of compliance with implementation of EAC decisions and directives are unlikely to be achieved at the current rate of implementation.

Under output 133103 on strengthening public awareness and public participation in EAC regional Integration, 4500 students $^{17}$ were sensitized about EAC integration against the annual target of 1200 . Only 14 out of the targeted ${ }^{18} 50$ LGs were sensitized on EAC integration process at half year stage showing that the target is unlikely to be achieved at the current rate of implementation by year end. No actuals were found on the output on Uganda's contribution to the EAC yet a target of $5.63 \$$ was set against the budget release of $15.18 \mathrm{bn}$ and $100 \%$ release.

\section{Ministry of Public Service}

The Ministry of Public Service (MoPS) received a total of UGX $137.915 \mathrm{bn} 45 \%$ of the approved annual budget and spent 43\% UGX $131.404 \mathrm{bn}$ ) of the release $.86 \%$ of the Ministry's output indicators are likely to be achieved at the current rate of implementation, while $14 \%$ of the indicators ware not assessed because data was missing. In regard to utilization of resources by half year, delivery on output indicators was $43 \%$ against $45 \%$ of the UG131.404bn (GOU + Donor) budget released; indicating that at mid-year, delivery on outputs is slower than release.

The indicators under the following outputs are likely to be achieved at the current rate of implementation; Public Service performance management, Management of the Public Service Payroll and Wage Bill, Results Oriented Management systems

instruments of ratification with the EAC Secretary General. Refer to Cabinet Minute Extract No. 271(CT2013), 2. Cabinet on $21^{\text {st }}$ November 2013 ratified the EAC Protocol on Cooperation in Defence Affairs and therefore authorized the Minister of foreign Affairs to deposit the instruments of ratification with the EAC Secretary General. Refer to Cabinet Minute Extract No. 491(CT2013), 3. Cabinet ratified the EAC Protocol on Peace and Security on $22^{\text {nd }}$ January 2014 and therefore authorized the Minister of foreign Affairs to deposit the instruments of ratification with the EAC Secretary General. Refer to Cabinet Minute Extract No. 271 (CT2013), 4. Cabinet Memo CT(2013)117 on Republic of Uganda hosting the $15^{\text {th }}$ Ordinary Summit of EAC Heads of State on $30^{\text {th }}$ November 2013.

${ }^{17}$ Intensified the sensitization in secondary schools and the formation and facilitation of EAC Clubs in such school. The education institutions visited include: Kawempe Muslim Secondary School, Kawanda Secondary School, Muyenga High school, St. Mary's College Kisubi , Nkumba University.

${ }^{18}$ The Local Governments include: Buyende, Kamuli, Gulu, Amuru and Nwoya 
Evaluating the Budget \& Efficiency of the Security, Justice \& Governance Cluster in Uganda 71

strengthened across MDAs and LGs, Compliance to service delivery standards, Service Delivery Standards Developed, Disseminated and Utilized. Under the output 131301 on developing and reviewing organizational structures for MDAs, the Ministry reported that 20 out of 30 MDAs and LGs had their organisational structures reviewed and customized by mid-year. This means that the annual target may be achieved at the end of the FY with more effort. By half year, the ministry reported that no retiring officers received preretirement training even though 95\% of the budget (UGX 0.31bn) was released. This would suggest that the annual target of covering $95 \%$ of the retiring officers is unlikely to be achieved at the current rate of implementation.

\section{Kampala Capital City Authority}

$35 \%$ of the Kampala Capital City Authority (KCCA) output indicators are likely to be achieved at the current rate of implementation, $7 \%$ of the output indicators may be achieved with additional effort, and $7 \%$ are unlikely to be achieved by year end, while $51 \%$ of the data was not assessed because there was insufficient data. In regard to budget efficiency by half year, delivery on output indicators was $28 \%$ against $563.8 \%$ of the UGX 7.651bn budget released; indicating that at mid-year, delivery on outputs is considerably slower than release.

Under the outputs on Urban Market Construction and rehabilitation; were not met by mid-year. KCCA reported that architectural designs for Busega Market were completed; procurement of contractor finalized and construction will commenced in June 2014. Under urban road maintenance, by half year, $2.9 \mathrm{Km}$ of Urban roads were maintained ${ }^{19}$ (sectional repairs) out of the annual target of $5 \mathrm{Km}$. this implies that the annual target is likely to be achieved by close of the financial year. The output target for the indicator under Urban Road Construction was outstripped by mid-year stage as $12.88 \mathrm{Km}$. of urban roads was constructed to bitumen standard more than the annual plan of $8 \mathrm{Km}$. The roads that were upgraded from gravel to bitumen include roads like Kamuli Link $(0.65 \mathrm{~km})$, Kintu/Kitintale road $(1 \mathrm{~km})$, Canoon $(0.85 \mathrm{~km})$, Circular drive $(0.8 \mathrm{~km})$, Corporation road (0.27), Access Road $(0.1 \mathrm{~km}), 2(0.06 \mathrm{~km})$ Wanainchi road $(0.4 \mathrm{~km})$ Martyrs $(0.27 \mathrm{~km})$ UNEB access road $(0.35 \mathrm{~km})$ Access Road $2(0.1 \mathrm{~km})$ Lakeside road $(1 \mathrm{~km})$, Radio Maria road $(0.55 \mathrm{~km})$, Mutungo road $1(0.75 \mathrm{~km})$, Kabalega Crescent Road

\footnotetext{
${ }^{19}$ This includes Old Mubende Rd and Kyabagu Rd.
} 
$(0.9 \mathrm{~km})$, Buvuma road $(0.27 \mathrm{~km})$ Muwafu $(0.23 \mathrm{~km})$ Martyrs' Rise $(0.05 \mathrm{~km})$, Martyrs' Drive $(0.25 \mathrm{~km})$ Martyrs gardens A and B $(0.5 \mathrm{~km}$ and Martyrs Link $(0.17 \mathrm{~km})$. This was done with $49 \%$ of the UGX $72.9 \mathrm{Bn}$ budget released. In addition, $14.09 \mathrm{Km}$. of urban roads were rehabilitated ${ }^{20}$ (Bitumen standard) by mid-year.

Under Primary Education infrastructure construction, 100 out of 100 Primary Schools benefited from infrastructure construction as staff quarters were constructed, staff quarters at Naguru Katali primary school in Nakawa Division, renovation of staff quarters at Ntinda primary school in Nakawa Division. Under the output of provision of Urban Health Services; $176,416,773$ against $516,416,713$ outreach programmes of the value of essential medicines delivered to health facilities by NMS were conducted. Therefore the output indicator target may be achieved if more effort is put in at the current rate of implementation. These include various outreaches conducted by KCCA health units to communities for immunisation, safety, hygiene, TB and sanitation improvement. These also included outreaches to cattle traders, butcher men, workers in factories, markets, slaughter houses, hotels and schools. Zero of the planned 9 health facilities reporting no stock out of the 6 tracker drugs was recorded; this is unlikely to be achieved.

\section{SECURITY SECTOR}

The objectives of the Sector are to preserve and defend the sovereignty and territorial integrity of Uganda, build adequate and credible defence to address both internal and external threats, provide intelligence information to support national security and stability, and create military alliances that enhance regional security and stability.

The Sector is led by the Ministry of Defence (MoD), and includes Internal Security Organization (ISO) and External Security Organization (ESO). While the Ministry for Security falls under this Sector, it is not a Vote of its own but its functions are spelt out in the Budget Framework Paper as coordination of security agencies under the Office of the President.

The Security sector received UGX 480.6 (41\%) of the annual budget of UGX 1159.29 bn-donor inclusive and spent $94 \%$ of the budget release. The sector registered 
Evaluating the Budget \& Efficiency of the Security, Justice \& Governance Cluster in Uganda 73

good performance at half year with $95 \%$ of the output targets likely to achieve the annual targets by financial year end if the implementation rate is maintained and $5 \%$ of the output targets may be achieved if additional effort is made. The Sector performance on utilization of funds shows that $79 \%$ of the output targets were delivered in line with the budget release.

Table 1.6: Half-Year Performance Scorecard for Security Sector OUTPUT PERFORMANCE

\begin{tabular}{|l|c|c|c|c|c|}
\hline & $\begin{array}{c}\text { Likely to be } \\
\text { Achieved }\end{array}$ & May be Achieved & $\begin{array}{c}\text { Unlikely to } \\
\text { be Achieved }\end{array}$ & $\begin{array}{c}\text { No } \\
\text { Assessment }\end{array}$ & Denominator \\
\hline Sector & $95 \%$ & $\mathbf{5 \%}$ & $\mathbf{0} \%$ & $\mathbf{0 \%}$ & $\mathbf{1 9}$ \\
\hline MoD & $89 \%$ & $11 \%$ & $0 \%$ & $0 \%$ & 9 \\
\hline IS0 & $100 \%$ & $0 \%$ & $0 \%$ & $0 \%$ & 5 \\
\hline ESO & $100 \%$ & $\%$ & $0 \%$ & $0 \%$ & 5 \\
\hline
\end{tabular}

BUDGET PERFORMANCE

\begin{tabular}{|l|c|c|c|c|c|c|}
\hline \multicolumn{1}{|c|}{ Budget } & $\begin{array}{c}\text { Approved } \\
\text { (UGX Bn) }\end{array}$ & $\begin{array}{c}\text { Released } \\
\text { (UGX Bn) }\end{array}$ & $\begin{array}{c}\text { Spent } \\
\text { (UGX Bn) }\end{array}$ & $\begin{array}{c}\text { \% of } \\
\text { budget } \\
\text { release }\end{array}$ & $\begin{array}{c}\text { \% of } \\
\text { release } \\
\text { spent }\end{array}$ & $\begin{array}{c}\text { \% of } \\
\text { budget } \\
\text { spent }\end{array}$ \\
\hline $\begin{array}{l}\text { Sector Total } \\
\text { (GoU+Donor) }\end{array}$ & $\mathbf{1 , 1 5 9 . 2 9}$ & $\mathbf{4 8 0 . 6 0}$ & $\mathbf{4 5 2 . 7 6}$ & $\mathbf{4 1 \%}$ & $\mathbf{9 4 \%}$ & $\mathbf{3 9 \%}$ \\
\hline $\begin{array}{l}\text { Sector Total } \\
\text { (GoU) }\end{array}$ & $\mathbf{9 0 6 . 0 4}$ & $\mathbf{4 8 0 . 6 0}$ & $\mathbf{4 5 2 . 7 6}$ & $\mathbf{5 3 \%}$ & $\mathbf{9 4 \%}$ & $\mathbf{5 0 \%}$ \\
\hline $\begin{array}{l}\text { MoD } \\
\text { (GoU+Donor) }\end{array}$ & $1,105.63$ & 449.33 & 421.69 & $41 \%$ & $94 \%$ & $38 \%$ \\
\hline MoD(GoU) & 852.39 & 449.33 & 421.69 & $53 \%$ & $94 \%$ & $49 \%$ \\
\hline $\begin{array}{l}\text { ISO } \\
\text { (GoU+Donor) }\end{array}$ & 39.77 & 24.33 & 24.22 & $61 \%$ & $99.6 \%$ & $61 \%$ \\
\hline ISO (GoU) & 39.77 & 24.33 & 24.22 & $61 \%$ & $99.6 \%$ & $61 \%$ \\
\hline $\begin{array}{l}\text { ESO } \\
\text { (GoU+Donor) }\end{array}$ & 13.88 & 6.94 & 6.86 & $50 \%$ & $99 \%$ & $49 \%$ \\
\hline ESO (GoU) & 13.88 & 6.94 & 6.86 & $50 \%$ & $99 \%$ & $49 \%$ \\
\hline
\end{tabular}




\section{EFFICIENCY ASSESSMENT}

\begin{tabular}{|l|c|c|c|c|}
\hline & $\begin{array}{c}\text { \% where output } \\
\text { performance is in } \\
\text { line with budget } \\
\text { released }\end{array}$ & $\begin{array}{c}\text { \% where output } \\
\text { performance is *not in } \\
\text { line with budget } \\
\text { released }\end{array}$ & No Assessment & Denominator \\
\hline Sector Total & $79 \%$ & $21 \%$ & $\mathbf{0 \%}$ & $\mathbf{1 9}$ \\
\hline MoD & $89 \%$ & $11 \%$ & $\mathbf{0} \%$ & $\mathbf{9}$ \\
\hline ISO & $40 \%$ & $60 \%$ & $\mathbf{0} \%$ & $\mathbf{5}$ \\
\hline ESO & $100 \%$ & $0 \%$ & $\mathbf{0} \%$ & $\mathbf{5}$ \\
\hline
\end{tabular}

*Where progress in performance indicators were proportional to financial releases at output level, in cases where progress in performance indicator was equal or above the releases.

\section{Ministry of Defence}

The total release to the Ministry by half year was UGX 449.33bn (22\%) of the approved annual budget of UGX1159.29bn and $94 \%$ of the release was spent. Efficiency assessment of the Ministry indicates that $89 \%$ of the output targets was delivered in line with the released funds. The performance of the Ministry at half year shows that $89 \%$ of the output indicators likely to be achieved by financial year end if the current rate of implementation is maintained and $11 \%$ may be achieved if additional effort is made. Indicators had already surpassed the annual budgets by half year on value of food stuff procured and supplied (140\% of UGX 18.9bn) - the MoD notes that the food budget does not have enough funds to cater for the entire feeding requirement, hence over performance in this area at half-annual hence the need for a funding increment of UGX $34.99 \mathrm{bn}$ on the budget to cater for this shortfall. Value of petroleum Oil and Lubricants (POL) procured also performed at 202\% of UGX10.3bn- also attributed to budget shortfall of UGX31.98bn.

Indicators that had already achieved the annual targets include: medicare services accessible to UPDF officers, militants and their families $(67 \%$, number of children enrolled in UPDF formal schools ( $100 \%$ of 40,842 school children), and number of category courses conducted for officers and militants (100\% of 6 courses). Other areas, which had registered good progress against their annual targets by half year are: procurement of uniforms (54\% of UGX 10.9bn), construction, renovation, and upgrading of several projects for officers and militants (55\% of 49 projects). 
Evaluating the Budget \& Efficiency of the Security, Justice \& Governance Cluster in Uganda 75

\section{Internal Security Organization}

By half of FY 2014/15, the Internal Security Organization (ISO) had received UGX 24.33bn (61\%) of the approved annual budget of UGX39.77bn and $99.6 \%$ of the release was spent. Half year performance assessment of Internal ISO shows that all (100\%) of the output indicators are likely to be achieved at the current rate of implementation. Performance assessment indicates that ISO was on track to achieve its annual targets in the areas of collection of technical and human intelligence and training of administration staff, training of ISO staff. However, the progress registered at half annual was not commensurate with the release since only $40 \%$ of ESO outputs indicators were delivered in line with budget released.

\section{External Security Organization}

The External Security Organization (ESO) received 50\% (UGX 6.94bn) of the approved budget of UGX $13.88 \mathrm{bn}$ and utilized $99 \%$ of the released funds. ESO was on track to achieve all its output indicators all (100\%) of the output performance indicator targets likely to be achieved at the current rate of implementation. These include weekly collection of technical intelligence and human intelligence and generation of intelligence reports and daily briefings to the President. The progress registered at half annual was commensurate with the release since $100 \%$ of ESO outputs indicators were delivered in line with budget released.

\section{DISCUSSION OF RESULTS}

Evaluation can be formative - where it is done during the initiation and design of an intervention and is thus interested in of improving the value of a proposal, project, or organisation; and, assumptive - where it draws lessons from a completed intervention. Evaluation involves: a systematic, rigorous, and meticulous application of scientific methods (Ross, Ellipse and Freeman, 2004), an objective and critical assessment focusing on facts as well as value laden judgments of the programs outcomes and worth (Reeve and Paperboy, 2007). While main purpose of evaluation can be to "determine the quality of a program by formulating a judgment" (Hurteau, Houle and Mongiat, 2009) various evaluations also serve various purposes with some serving a monitoring function rather than focusing solely on measurable program outcomes or evaluation findings and a full list of types of evaluations would be difficult to compile (Reeve and Paperboy, 2007). 
GoU, (2013) points out that plans are not being designed with performance in mind, routine monitoring is uneven in scope and quality, and evaluation is sparse in coverage and use. In the Uganda public service for example, the Government has also realized that stronger coordination is needed to ensure that monitoring and evaluation helps guide public actions toward greater cost-effectiveness in pursuit of poverty eradication and to improve information standards, requirements, and systems that support different levels of national decision-making (GoU, 2013). With regard time constraints, an evaluator may face the challenges that include: too many activities that were poorly planned for while scheduling that they overwhelm the evaluator as time will be elapsing without completing activities on schedule. Data constraints include the challenge of accessing some respondents that Bamberger, Rugh and Mabry (2006) termed as hard to reach, additionally; there may be covert resistance by some organisational members to provide the evaluator with required information which causes some frustration in the process.

\section{CONCLUSIONS}

The Government Half Annual Performance Report provides information on the performance of Government at mid-point of the current Financial Year (FY) 2014/15. The objective of the report is to highlight areas where progress has been made against the set targets and actions and where delays have been occasioned. This report is therefore intended to aid Cabinet and line Ministries, Departments and Agencies, and Local Governments to support Government in ensuring that agreed targets are met by the end of the Financial Year. Budget releases to sectors and their constituent Ministries, Departments and Agencies are uneven at mid -year point. Sectors like, Accountability, Justice Law and Order, Legislature, Public Administration and Public Sector Management all received over half of their annual budgets (Government component only, excluding donor contributions) in the first two quarters, while others have received considerably less than expected. Amongst these Securities has not received more than $45 \%$ of their annual budgets (Government component only) by the half-year stage. The Security, Public Administration, Justice Law and Order are making good progress.

In conclusion, there is evidence of improving endogenous demand for monitoring evidence. In Uganda there is increasing performance reporting in Cabinet with the reports discussed on a regular basis, showing a high level demand for M\&E evidence. 
Evaluating the Budget \& Efficiency of the Security, Justice \& Governance Cluster in Uganda 77

Monitoring dominates the M\&E systems in all cases, and there are issues with the results orientation, scope and quality of data of the monitoring systems. This article has built on some of the work done by the technical officers in the monitoring and evaluation department of the Office of the Prime Minister on M\&E systems, building not from a donor demand, but in-country demand. As a result, there are emerging efforts from the ministries, departments and Agencies to build on each other's experience, with an active exchange programme happening between OPM and MDA's, around evaluation. International organizations like 3ie, UNDP and donors (DFID) are actively supporting this sharing. This should help to reduce donor dominance, both in terms of concepts and instruments, help to reinforce in-country capacity to develop M\&E systems, and build local confidence.

In Uganda the lead agency collates information from other departments and so is dependent upon the capacity of other agencies to produce quality information. Monitoring reports are generally widely disseminated and in all cases considerable human and financial resources are put into their development. Results have shown that in Uganda, there is a system of biannual Cabinet retreats to review the performance of the government. The President, Vice president, Prime Minister, Ministers, top public servants and local government leaders attend the retreat. The retreats review reports and issue recommendations to inform budgeting processes of the following years. In this way, there are emerging mechanisms to institutionalize monitoring to feed into executive decision-making processes in order to improve budgeting and effectiveness in service delivery. However, what remain unclear are the consequences of poor performance and the rigor of the evaluative decisions that are taken.

\section{POLICY IMPLICATIONS}

In evaluating the sector budgets and efficiency retreats of Cabinet Ministers, Ministers of State, Permanent Secretaries and Local Government Officials to assess the performance of Government have been held since the Financial Year 2009/10. The reviews are based on the findings of the Government Annual Performance Report (GAPR) and (GHAPR) produced by the Office of the Prime Minister. In line with key medium term objective, the performance reports provide timely information to policy makers on the performance of Government during the previous financial year, highlighting what has been delivered, what has not, and the reasons why. Fundamentally, the report is designed and timed to 
inform the key policy makers on where resources and efficiency measures need to be placed in the coming financial year.

The purpose of the Retreats is to look critically at the performance of Government against intended outcomes and planned actions and output targets and resource usage across the sectors that constitute the planning and budgeting framework of all the Government and whether or not these actions and outputs remain appropriate to the achievement of sustainable results in economic infrastructure and competitiveness, service delivery in rural and human development, and ensuring security, justice and good governance. During the retreats, Ministers make presentations on the performance of each sector from the Office of the Prime Minister. After presentation and discussion of the performance of a particular sector, the plenary suggests specific actions that should be adopted to rectify the policy or implementation issues highlighted. The Cabinet then endorses the actions, and relevant Ministries Departments and Agencies are requested to plan and implement the actions in the following year. They are further followed-up to ensure that implementation has been done.

Further in-depth work is needed, which will both help to deepen the analysis and also lead to more in-depth sharing across government ministries. Some fruitful follow-up work could be undertaken from four perspectives: (1) citizens, (2) line ministries, (3) parliaments and (4) the profession of evaluation. In this analysis, there is a gap in knowledge of how citizen demands for development spur government demands for monitoring and evaluation. Filling this gap would be important given the appearance of an increasingly active citizenry in Uganda. An investigation of line ministries would give a deeper political perspective on how the centralized rules and incentives play out in practice. The use of M\&E information by parliaments provides an opportunity for increased demand and use of M\&E information for accountability. Parliaments are locations of latent demand for evaluation, where there is space for contestation around evidence. Finally, deeper analysis of the profession of evaluation would give an indication of the gaps between government demand and the current supply as governments start to regulate the markets they generate as they commission evaluation. 
Evaluating the Budget \& Efficiency of the Security, Justice \& Governance Cluster in Uganda 79

\section{List of References}

- Atkinson, D., Wilson, M., \& Avula, D. 2005. A participatory approach to building capacity of treatment programs to engage in evaluation. Evaluation and Program Planning, 28(3), 329334.

- Bamberger, M. J., Rugh, J and Mabry, L. 2006. Real World Evaluation: Working Under Budget, Time, Data, and Political Constraints. Sage.

- Batley, R, McCourt, W. and Mcloughlin, C. 2011. 'The Politics and Governance of Public Services in Developing Countries' at the annual conference of the International Research Society for Public Management in Dublin in April 2011

- Coats, D. 2006. Reviving the Public: A New Governance and Management Model for Public Services, paper prepared for New Zealand Public Services Association on behalf of The Work Foundation, London.

- Cousins, J. B., Goh, S. C., Elliott, C. J., \& Bourgeois, I. 2014. Framing the capacity to do and use evaluation. In J. B. Cousins \& I. Bourgeois (Eds.), Organizational capacity to do and use evaluation. New Directions for Evaluation, 141, 7-23

- $\quad$ Del Tufo, S. 2002. "What is evaluation?" Evaluation Trust. The Evaluation Trust.

- Government of Uganda, 2013. National Policy on Public Sector Monitoring and Evaluation. Office of the Prime Minister, Kampala-Uganda.

- Gildenhuys, J.S.H., 1997. Public financial management. Pretoria: J.L. van Schaik

- Horton, D., Alexaki, A., Bennett-Lartey, S., et al. 2003. Evaluating capacity development: Experiences from research and development organizations around the world. The Hague: International Service for National Agricultural Research

- Hurteau, M.; Houle, S.; Mongiat, S. 2009. "How Legitimate and Justified are Judgments in Program Evaluation?". Evaluation 15 (3): 307-319. doi:10.1177/1356389009105883.

- Institute of Development Studies (IDS). 1998. Participatory Monitoring and Evaluation. IDS Policy Briefing, (12). Accessed from: www.ids.ac.uk/ids/bookshop/briefs/brief12.html 
- Kitamura, Y. 2009, Education Indicators to Examine the Policy-Making Process in the Education Sector of Developing Countries, available online at: http://ir.nul.nagoyau.ac.jp/jspui/bitstream/2237/14055/1/170.pdf

- Lennie, J., Tacchi, J. \& Wilmore, M. 2010. Critical reflections on the use of participatory methodologies to build evaluation capacities in international development organisations. $8^{\text {th }}$ World Conference on action research and action learning. Melbourne. Australia.

- Mofolo, M; Mkuyane L; \& Skade, T.2014. Actions And Behaviours Essential For Monitoring and Evaluation to Succeed in South Africa, Africa's Public Service Delivery And Performance Review, Volume 2 (3), Pp,5-24

- Porter, S.,Goldman, I.,2013, 'A Growing Demand for Monitoring and Evaluation in Africa', African Evaluation Journal 2013;1(1), Art. \#25, 9 pages. http://dx.doi.org/10.4102/aej.v1i1.25

- Rabie, B. and Cloete, F. 2009. A new typology of monitoring and evaluation approaches. Administratio Publica. 17(3): 76-97.

- Reeve, J and Paperboy, D. 2007. "Evaluating the evaluation: Understanding the utility and limitations of evaluation as a tool for organizational learning". Health Education Journal 66 (2): 120 -131. doi:10.1177/0017896907076750.

- Ross, P.H. Ellipse, M.W. and Freeman, H.E. 2004. Evaluation: A systematic approach (7th ed.). Thousand Oaks: Sage.

- Stockman, R. and Meyer, W. 2013. Functions, Methods and Concepts in Evaluation Research, Palgrave, Macmillan.

\section{AUTHORS' CONTACT:}

\begin{tabular}{|c|c|}
\hline $\begin{array}{r}\text { BYAMUGISHA, Albert } \\
\text { Commissioner, } \\
\text { Monitoring \& Evaluation } \\
\text { Office of the Prime Minister } \\
\text { Uganda }\end{array}$ & $\begin{array}{l}\text { BASHEKA, Benon C. } \\
\text { Dean, } \\
\text { School of Business \& Management } \\
\text { Uganda Technology \& Management Univ. } \\
\text { Email: bbasheka@yahoo.co.uk }\end{array}$ \\
\hline
\end{tabular}

